\title{
O GÊNERo LEANDra, SEÇões Carassanae, ChaETodon, Niangae, Oxymeris E SeCUndiflorae (Melastomataceae) NO ESTADO DOP ARANÁ
}

\author{
Eduardo Antonio de Camargo ${ }^{1}$, Caroline M. Fogaça de Souza ${ }^{2}$, \\ Mayara Krasinski Caddah \& Renato Goldenberg ${ }^{2}$
}

\begin{abstract}
RESUMO
(O gênero Leandra, seções Carassanae, Chaetodon, Niangae, Oxymeris e Secundiflorae (Melastomataceae) no estado do Paraná) O gênero Leandra pode ser reconhecido pelas folhas destituídas de formicários, inflorescências terminais e/ou pseudo-axilares, pétalas florais com ápice agudo/acuminado e frutos carnosos. $\mathrm{Na}$ última revisão do gênero, o mesmo foi dividido em sete seções, reconhecidas com base na posição e tipo da inflorescência, presença e tipo de tricomas e morfologia das sementes. Neste trabalho são apresentadas chave de identificação, descrições, ilustrações e dados sobre a distribuição geográfica das 43 espécies ocorrentes no Paraná, e pertencentes a cinco seções de Leandra: Carassanae, Chaetodon, Niangae, Oxymeris e Secundiflorae.
\end{abstract}

Palavras-chave: taxonomia, flora, Brasil.

\section{Abstract}

(The genus Leandra, sect. Carassanae, Chaetodon, Niangae, Oxymeris e Secundiflorae (Melastomataceae) in the state of Paraná) The genus Leandra can be recognized by the leaf blades without formicaria, terminal and/or pseudo axillary inflorescences, by the acute/acuminate petals and freshy fruits. In the last revision of the genus, its was divided into seven sections, based on inflorescence type and position, presence and type of hairs and seed morphology. Here we present identification keys, descriptions, illustrations and data on geographic distribution for the 43 species from five sections of Leandra occuring in the state of Paraná: Carassanae, Chaetodon, Niangae, Oxymeris, and Secundiflorae.

Key words: taxonomy, flora, Brazil.

\section{INTRODUÇÃO}

Melastomataceae apresenta cerca de 4.570 espécies, pertencentes a 150-166 gêneros (Renner 1993). Embora esteja distribuída pantropicalmente, a família concentra um número maior de espécies no Novo Mundo, onde ocorrem cerca de 2.950 espécies (Renner 1993). Já o gênero Leandra apresenta cerca de 200 espécies, distribuídas desde o México e Antilhas, até o sul do Brasil e Argentina (Cogniaux 1891; Judd \& Skean 1991; Martin et al. 2008). No Brasil, o gênero está representado por cerca de 150 espécies e pode ser reconhecido pelas folhas destituídas de formicários, inflorescências terminais e/ou pseudo-axilares, pétalas com ápice agudo/acuminado e frutos carnosos (Cogniaux 1886-1888; Wurdack 1962; Judd \& Skean 1991; Camargo \& Goldenberg 2007; Martin et al. 2008).
A distinção de Leandra em relação às espécies dos gêneros Ossaea, Clidemia, Miconia e Pleiochiton frequentemente não é muito clara (Judd 1986; Judd \& Skean 1991; Michelangeli et al. 2004). As espécies de Miconia possuem pétalas com ápice arredondado e dente externo do cálice curto (Goldenberg 2004), as de Clidemia possuem inflorescências laterais e/ou pseudo-laterais e pétalas com ápice arredondado, enquanto que Pleiochiton possui hábito sempre epifítico (Goldenberg et al. 2005). A distinção em relação a Ossaea é mais complicada, e é feita com base na posição das inflorescências: em Ossaea as inflorescências são sempre axilares, enquanto que em Leandra elas são terminais, mas podem ser também pseudo-axilares, o que dificulta o reconhecimento e delimitação dos gêneros (Goldenberg et al. 2005).

Artigo recebido em 05/2008. Aceito para publicação em 05/2009.

${ }^{1}$ Curso de Pós-Graduação em Botânica / UFPR e-mail: edcamarg @ hotmail.com bolsista CNPQ.

${ }^{2}$ UFPR, SCB, Depto. Botânica, C.P. 19031, 81531-970, Curitiba, PR. e-mail: rgolden@ufpr.br bolsista CNPq. 
Cogniaux (1891) na revisão completa do gênero o dividiu em sete seções, reconhecidas com base na posição e tipo da inflorescência, presença e tipo de tricomas e morfologia das sementes. A circunscrição destas seções em geral é bastante discutível, sendo Leandraria DC., Secundiflorae Cogn. e Tschudya Cogn. as únicas razoavelmente bem definidas (Wurdack 1962), sendo que esta última não ocorre no estado do Paraná. A seção Carassanae Cogn. não apresenta características marcantes, suas espécies apresentam: panículas terminais, inflorescências nunca escorpióides, além do hipanto com indumento pubescente ou estrigoso, não híspido, e sementes piramidais, sem apêndices (Cogniaux 1886-1888). A seção Chaetodon Cogn. pode ser reconhecida pelas inflorescências terminais no início do desenvolvimento, passando a pseudo-axilares posteriormente. A seção Niangae Cogn. difere das demais por possuir ramos com indumento hirsuto (tricomas com a base levemente alargada, eretos e rígidos) e hipanto com constrição no ápice. A seção Oxymeris Cogn. compartilha as mesmas características da seção Carassanae, mas difere pela presença de indumento nos ramos e hipanto, normalmente glabros. Já a seção Secundiflorae Cogn. caracteriza-se pelas inflorescências escorpióides, e pelas sementes ovais e tuberculadas. Dados sobre o número de espécies para todas as seções são escassos (Cogniaux 1886-1888).

Este trabalho tem como objetivo contribuir para o conhecimento de um grupo importante e frequente no estado, adicionando informações para a Flora do Paraná. São apresentados os dados sobre todas as espécies de Leandra ocorrentes no estado, à exceção das pertencentes à seção Leandraria, já apresentadas em Camargo \& Goldenberg (2007).

\section{Material e Métodos}

O presente trabalho é baseado em coletas depositadas nos herbários paranaenses EFC, FUEL, HUPG, HUEM, MBM, UPCB, além do R, RB, SP e HBR (acrônimos segundo The New York Botanical Garden). Para cada espécie, apenas as coletas provenientes do Paraná foram listadas como "material selecionado", a partir das quais se basearam as descrições. Quando necessário, devido à escassez de coletas, foi citado "material adicional", proveniente de outros estados. Apenas uma coleta por município foi listada, sendo, neste caso, selecionados os registros mais recentes.

Com relação à morfologia, o número de nervuras laterais das folhas foi complementado com um sinal de "mais" e o número dois quando constatou-se a ocorrência de um par submarginal tênue adicional (p.ex., figuras $2 \mathrm{t}$ e $2 u$ : $3+2$ nervuras, com 1 nervura principal, 2 secundárias e mais o par tênue).

Algumas espécies possuem características únicas que, apesar de terem sido utilizadas na chave de identificação, foram citadas apenas nos comentários de cada espécie. As medidas dos tricomas estrelados não constam nas descrições, pois todas as medidas não ultrapassam 0,3 mm compr. A chave de identificação de espécies admite múltiplas entradas. As espécies da seção Leandraria constam apenas na chave de identificação (para as descrições, ver Camargo \& Goldenberg 2007). A distribuição geográfica e os dados de floração das espécies foram descritas com base nas coleções presentes nos herbários visitados e coletas em campo.

Taxons infra-específicos não foram aceitos para este trabalho. Para a listagem de sinonímias e tipos ver Cogniaux (1891) e Wurdack (1962).

\section{O estado do Paraná}

O Paraná está localizado na Região Sul do Brasil, entre 22'29'30"e 26²' 59" Sul, e $48^{\circ} 02^{\prime} 24^{\prime \prime}$ e 543' $38^{\prime \prime}$ Oeste. Dados sobre o ambiente físico e biológico do estado podem ser encontrados em Ambientebrasil (2007), Maack (1968) e Goldenberg (2004). O Paraná possui um relevo onde predomina um vasto planalto com uma pequena inclinação nas direções noroeste, oeste e sudoeste do estado. São reconhecidas cinco unidades geomorfológicas que se sucedem de leste para oeste: Litoral, 
Serra do Mar, Primeiro Planalto ou de Curitiba, Segundo Planalto ou de Ponta Grossa e Terceiro Planalto ou de Guarapuava (Maack 1968). No Paraná ocorrem 5 regiões fitoecológicas: (1) floresta ombrófila densa (FD) no Litoral, Serra do Mar e porção norte do Primeiro Planalto, com áreas de formações pioneiras, como restingas, manguezais e comunidades aluviais, além dos subtipos altomontana (acima de $1000 \mathrm{~m}$ ), montana (400-1000 m), submontana (30-400 m) e terras baixas $(0-30 \mathrm{~m})$; (2) floresta ombrófila mista (FOM) nas regiões mais altas nas regiões planaltinas central e sul do estado; (3) floresta estacional semidecidual (FE), no norte e oeste do segundo e terceiro planaltos; (4) estepe ombrófila (CA), no planalto de Ponta Grossa principalmente; (5) savana (CE) em manchas isoladas no norte do estado (Roderjan et al. 1993; Leite 1994).

\section{Resultados e Discussão}

Leandra Raddi, Mem. Soc. Ital. Sc. 18: 385. 1820.

Subarbustos a árvores com indumento variável. Folhas opostas, pecioladas ou sésseis, nervuras 3-9 acródromas basais a suprabasais. Panículas terminais ou pseudo-axilares, glomerulares ou não, menos freqüentemente com ramos adicionais laterais ou axilares; brácteas caducas ou persistentes, involucrais ou não. Flores (4-)5(-7)-meras; hipanto campanulado ou tubuloso; cálice verde a avermelhado, duplo, com lacínias; pétalas alvas a rosadas, lineares a estreitamente triangulares, ápice agudo a acuminado; estames geralmente isomórficos, anteras alvas a róseas, usualmente oblongas, raro subuladas ou obovadas, uniporosas, conectivo normalmente pouco ou não prolongado abaixo das tecas, com apêndice dorso-basal ou inapendiculado; ovário ínfero, 3-5-locular, ápice glabro ou com tricomas; estilete filiforme, normalmente glabro, estigma puntiforme. Frutos bacáceos, com muitas sementes, ovais a piramidais, lisas ou tuberculadas.

No Paraná, o gênero Leandra está representado por 50 espécies, sendo que sete pertencem à seção Leandraria (Camargo \& Goldenberg 2007), e 43 pertencem às seções Carassanae (14 spp.), Chaetodon (14 spp.), Niangae (6 spp.), Oxymeris (8 spp.) e Secundiflorae (1 sp.). Neste trabalho optouse por elaborar uma única chave de identificação e também apresentar as espécies sem distinção das seções, visto que a delimitação destas seções não é muito clara.

\section{Chave de identificação para as espécies de Leandra no Paraná}

1. Panículas com flores reunidas em glomérulos; brácteas e bractéolas involucrais (seção Leandraria ${ }^{1}$ ).

2. Panículas com flores envolvidas por brácteas caducas

L. bergiana

2.' Panículas com flores envolvidas por brácteas persistentes 3

3. Folhas com nervuras basais; anteras brancas ........................................... eichleri

3.' Folhas com nervuras suprabasais; anteras róseas ou verde-azuladas .................... 4

4. Folhas com base amplexicaule; margem da lâmina lisa......... L. amplexicaulis

4.' Folhas com base de outro tipo; margem da lâmina denticulada

5. Ramos com tricomas 3,2-4,4 mm compr.; cálice com lacínias externas maiores do que as internas L. pubistyla

5.' Ramos com tricomas $0,6-1,8 \mathrm{~mm}$ compr.; cálice com lacínias externas menores ou até do mesmo tamanho do que as internas ........................... 6

6. Folhas ovais; anteras verde-azuladas; ovário 3-locular ...... L. sericea

6.' Folhas lanceoladas; anteras róseas; ovário 4-locular .......................... 7

7. Face abaxial das brácteas com indumento presente somente na porção central, deixando as margens glabras .L. fragilis

$\overline{{ }^{1} \text { As descrições e materiais examinados das espécies de Leandra seção Leandraria estão em Camargo \& Goldenberg (2007) }}$ 
7.' Face abaxial das brácteas com indumento presente por toda a face, incluindo as margens L. melastomoides

1.'Panículas com flores geralmente não reunidas em glomérulos; se glomerulares, com brácteas e bractéolas reduzidas e não involucrais.

8. Folhas com a face adaxial glabra ou somente com tricomas estrelados.

9. Folhas lineares 38. L. salicina

9.' Folhas com outra forma, nunca lineares.

10. Ramos da inflorescência com indumento hirsuto, com tricomas simples de $3-6,5 \mathrm{~mm}$ compr. 12. L. echinata

10.' Ramos da inflorescência glabros ou furfuráceo-estrelados, com indumento não hirsuto, tricomas simples, quando presentes, até $2 \mathrm{~mm}$ compr.

11. Lacínias externas do cálice até $1 \mathrm{~mm}$ compr.

12. Face abaxial das folhas com tricomas simples na base das nervuras primárias, formando domácias.

13. Folhas membranáceas, nervuras claramente suprabasais, margem lisa (fig. 2c). 1. L. acutiflora

13.' Folhas cartáceas ou coriáceas, nervuras curtamente suprabasais, margem revoluta (fig. $2 \mathrm{k}$ ). 32. L. quinquedentata

12.' Face abaxial das folhas sem tricomas simples na base das nervuras primárias.

14. Folhas coriáceas, com margem revoluta; pétalas com tricomas glandulares.

15. Folhas com nervuras laterais na face adaxial não visíveis e não nitidamente demarcadas; 3 nervuras basais fig. (2v) ......

27. L. neglecta

15.' Folhas com nervuras na face adaxial visíveis e nitidamente demarcadas; 3 a $3+2$ nervuras curtamente suprabasais

32. L. quinquedentata

14.' Folhas membranáceas ou cartáceas, com margem não revoluta; pétalas glabras.

16. Folhas cartáceas; face abaxial com tricomas simples ao longo da nervura principal

4. L. barbinervis

16.' Folhas membranáceas; face abaxial sem tricomas simples ao longo da nervura principal.

17. Folhas ovais, nervuras 3 a $3+2$ basais

18. Ramos jovens com tricomas simples

28. L. pallida

18.' Ramos jovens sem tricomas simples

5. L. calvescens

17.' Folhas elípticas, nervuras $3+2$ suprabasais.

19. Ramos jovens cilíndricos, folhas com a margem lisa e a base obtusa a cuneada (fig. 1u) ..... 1. L. debilis

19.' Ramos jovens levemente achatados, folhas com a margem denticulada ciliada e a base atenuada (fig. 2q) . 17. L. gracilis

11.' Lacínias externas do cálice com mais de 1,2 mm compr.

20. Panículas glomeruliformes (fig. 3b). 
21. Folhas ovais, pecíolo até $0,5 \mathrm{~cm}$ compr. (fig. $2 \mathrm{~b}$ )

30. L. polystachya

21.' Folhas lanceoladas ou estreitamente elípticas, pecíolo com mais de $1 \mathrm{~cm}$ compr. (fig. 1d) 16. L. glabrata

20.’ Panículas não glomeruliformes (fig. 3a).

22. Folhas cartáceas ou coriáceas; brácteas e bractéolas folhosas.

23. Lâmina foliar até $7 \mathrm{~cm}$ compr. (fig. 2d); pétalas 5-5,7 mm compr; lacínias do cálice caducas no fruto 39. L. sulfurea

23.' Lâmina foliar até $13 \mathrm{~cm}$ compr. (fig. 2a); pétalas 3-4 mm compr.; lacínias do cálice persistentes no fruto 35. L. reitzii

22.' Folhas membranáceas; brácteas não folhosas.

24. Folhas oblongo-lanceoladas; ovário 3-locular (fig. 2h)

29. L. pilonensis

24.' Folhas elípticas a ovais; ovário 5-locular (fig.1f)

23. L. laevigata

8.' Folhas com a face adaxial com tricomas simples, às vezes mesclados com tricomas ramificados.

25. Ramos jovens e da inflorescência quadrangulares, alados; face adaxial com indumento escabroso 40. L. tetraquetra

25.' Ramos jovens e da inflorescência cilíndricos ou achatados, nunca quadrangulares; face adaxial com outro tipo de indumento.

26. Ramos jovens com indumento glanduloso.

27. Panícula escorpióide (fig. 3c)

36. L. reversa

27.' Panícula não escorpióide

28. Ramos glanduloso-pubescentes e furfuráceo-estrelados; ápice do ovário com tricomas 9. L. cordigera

28.' Ramos somente glanduloso-pubescentes; ápice do ovário glabro

8. L. cordifolia

26.' Ramos jovens com indumento de outro tipo, nunca glanduloso.

29. Ramos jovens com indumento hirsuto (fig. $3 n$ ).

30. Face adaxial da folha com tricomas $0,8-1,2 \mathrm{~mm}$; lacínias externas do cálice menores do que as internas (fig. 3e) 42. L. xanthostachya

30.' Face adaxial da folha com tricomas 1,5-3,3 mm; lacínias externas do cálice maiores do que as internas.

31. Face adaxial da lâmina foliar bulada, e face abaxial foveolada; anteras vinosas

15. L. foveolata

31.' Faces adaxial e abaxial da lâmina planas ou onduladas; anteras amarelas.

32. Anteras 4,5-5 mm compr. (fig. 3i); ovário 4-locular

41. L. xanthocoma

32.' Anteras 2,5-3,8 mm compr.(fig. 3h); ovário 3-locular

3. L. australis

29.' Ramos jovens com indumento furfuráceo-estrelado, estrigoso-dendrítico ou pubescente (Figs. 3m, 3o, 3q-r).

33. Ramos com indumento estrigoso-dendrítico (figs. $3 \mathrm{~m}$ e $3 \mathrm{r}$ ).

34. Folhas diminutas, com até $3 \mathrm{~cm}$ compr. (fig. 1s) ... 26. L. microphylla

34.' Folhas grandes, com mais de 4,5 cm compr.

35. Anteras róseas, 2,6-4 mm compr.; cálice com lacínias externas $1,5-3,2 \mathrm{~mm}$ compr. 6. L. carassana

35.' Anteras alvas, 1,4-1,8 mm compr.; cálice com lacínias externas $0,7-1,2 \mathrm{~mm}$ compr. 10. L. dasytricha

33.' Ramos com indumento furfuráceo-estrelado, estrigoso ou pubescente (figs. $3 \mathrm{~m}, 3 \mathrm{o}, 3 \mathrm{q})$. 
36. Face abaxial das folhas com nervuras transversais oblíquas, ascendentes (fig. 1j) 37. L. riograndensis

36.' Face abaxial das lâminas com nervuras transversais não oblíquas, nem ascendentes.

37. Folhas ovais ou orbiculares, com nervuras basais.

38. Brácteas envolvendo a base do hipanto; panículas pequenas $(0,5-3 \mathrm{~cm}$ compr.) .... 19. L. humilis

38.' Brácteas não envolvendo o hipanto; panículas grandes (acima de $5 \mathrm{~cm}$ compr.)

39. Pecíolos com mais de $0,9 \mathrm{~cm}$ compr. 2. L. aurea

39.' Pecíolos com até $0,5 \mathrm{~cm}$ compr.

40. Folhas geralmente orbiculares; com indumento nas faces adaxial e abaxial (fig. 2s). 13. L. erostrata

40.' Folhas geralmente ovais; com indumento somente na face abaxial (fig. 2b) 30. L. polystachya

37.' Folhas lanceoladas, oblongo-lanceoladas, oval-lanceoladas e elípticas; se ovais, com nervuras suprabasais.

41. Face abaxial da lâmina com indumento viloso (fig. 3p).

42. Lacínias externas do cálice $2-4,5 \mathrm{~mm}$ compr.; anteras amarelas

31. L. purpurascens

42.' Lacínias externas do cálice 1-2,2 mm compr.; anteras róseas.

43. Folhas com a base cuneada, nervuras suprabasais (fig. 1c)....14. L. fallax

43.' Folhas com a base cordada a obtusa, nervuras basais (fig. 1g)... 2. L. aurea

41.' Face abaxial da lâmina com indumento furfuráceo-estrelado ou pubescente (figs. 3o, 3q).

44. Folhas com nervuras basais.

45. Face adaxial com tricomas dispostos em linhas; ápice do ovário glabro ......

21. L. itatiaiae

45.' Face adaxial com tricomas não dispostos em linhas; ápice do ovário com tricomas

7. L. catharinensis

44.' Folhas com nervuras suprabasais.

46. Face abaxial da lâmina com indumento exclusivamente furfuráceo-estrelado (fig. 3q)

18. L. hatschbachii

46.' Face abaxial da lâmina com indumento pubescente, mesclado ou não ao indumento furfuráceo-estrelado.

47. Ovário 5-locular

33. L. refracta

47.' Ovário 3-(4)-locular.

48. Lacínias externas do cálice acima de $3 \mathrm{~mm}$ compr.

49. Base da lâmina obtusa a cuneada (fig. 2r); ápice do ovário com tricomas simples

20. L. ionopogon

49.' Base da lâmina longamente atenuada (fig. 1q); ápice do ovário glabro

25. L. longisetosa

48.' Lacínias externas do cálice até $2,5 \mathrm{~mm}$ compr.

50. Lâmina com aréolas $0,3-0,5 \mathrm{~mm}$ diâmetro, nitidamente marcadas.

51. Lacínias externas do cálice $0,3-0,5 \mathrm{~mm}$ compr, sendo as internas maiores que as externas 24. L. laxa

51.' Lacínias externas do cálice 1,5-2,5 mm compr., sendo as internas menores que as externas 22. L. kleinii

50.' Lâmina com aréolas maiores que $1 \mathrm{~mm}$ diâmetro, não nitidamente marcadas. 
52. Nervuras 3+2; lacínias externas do cálice $0,4-0,8 \mathrm{~mm}$ compr. 11. L. debilis

52.' Nervuras 5+2; lacínias externas do cálice $1-1,8 \mathrm{~mm}$ compr.

53. Lâmina na face adaxial com tricomas $0,4-0,5 \mathrm{~mm}$; anteras amarelas..... 34. L. regnellii

53.' Lâmina na face adaxial com tricomas $1,2-1,8 \mathrm{~mm}$; anteras róseas

43. Leandra sp.

1. Leandra acutiflora (Naudin) Cogn. in Mart. \& Eichler, Fl. bras. 14(4): 162. 1886. Sect. Oxymeris.

Fig. 2c

Arbustos 0,7-3 m alt. Ramos jovens cilíndricos, glabros a esparsamente furfuráceoestrelados. Folhas com pecíolos $0,5-3,2 \mathrm{~cm}$ compr.; lâmina 5-12 × 1,5-5 cm, membranácea, elíptica a oblongo-elíptica, ápice acuminado, margem lisa, base atenuada, nervuras $3+2$ suprabasais; faces adaxial e abaxial glabras, face abaxial com tricomas simples na base das nervuras primárias, formando domácias. Panículas 3,3-10,3 cm compr.; brácteas 0,5-2 $\mathrm{mm}$ compr; bractéolas 0,5-0,6 mm compr. Flores 5-meras; hipanto 2-2,5 mm compr; cálice com tubo $0,1-0,2 \mathrm{~mm}$ compr., lacínias internas 0,3-0,4 mm compr., triangulares, lacínias externas $0,4-0,5 \mathrm{~mm}$ compr., cilíndricas a lineares; pétalas $2-3,5 \mathrm{~mm}$ compr.; estames 10, conectivo inapendiculado, antera 1,3-1,8 mm compr., alva; ovário 1,82,5 mm compr., 3-locular, ápice glabro. Frutos 4,5-11,5 ×4-10 mm, 460-540 sementes, 0,7$0,8 \times 0,3-0,4 \mathrm{~mm}$.

Material selecionado: Adrianópolis, 13.I.2000, fl.,I. Isernhagen 327 (UPCB). Balsa Nova, 16.X.2005, bot., $R$. Goldenberg 700 (UPCB). Campina Grande do Sul, XII.1972, fl., G. Hatschbach 31003 (MBM). Guaratuba, 30.XI.1958, fl., G. Hatschbach 5237 (MBM, UPCB). Morretes, XII.2001, fl., P. Labiak 2047 (MBM). Piraquara, 1.VIII.2004, fr., M. Reginato 42 (UPCB). Ponta Grossa, XII.1971, fl., L. Krieger 11184 (MBM, RB). Quatro Barras, IV.1994, fr., J. Silva 1315 (UPCB). São José dos Pinhais, XII.1982, fl., R. Kummrow 2133 (MBM).

Distribuição: Rio de Janeiro, São Paulo, Paraná e Santa Catarina. No Paraná ocorre na Serra do Mar, Primeiro e Segundo Planaltos, em FD altomontana e montana, FOM e CA.

Esta espécie caracteriza-se pelas folhas membranáceas, elípticas a oblongo-elípticas, com ápice acuminado e base atenuada. Os ramos são esparsamente furfuráceo-estrelados e as folhas são essencialmente glabras, com a face abaxial portando tricomas na base das nervuras primárias, formando domácias. Pode ser confundida com L. gracilis, que difere pelas folhas com margem denticulada ciliada e indumento furfuráceo-estrelado nos ramos e folhas. Assemelha-se também a L. barbinervis, que difere pelas folhas maiores, cartáceas, com nervuras basais ou curtamente suprabasais com indumento furfuráceo-estrelado. Coletada com flores entre novembro e janeiro, com frutos entre fevereiro e abril e em agosto.

2. Leandra aurea (Cham.) Cogn. in Mart. \& Eichler, Fl. bras. 14(4): 142. 1886. Sect. Carassanae.

Fig. $1 \mathrm{~g}$

Arbustos a arvoretas 0,6-2 m alt. Ramos jovens cilíndricos, moderadamente furfuráceoestrelados e moderado a densamente estrigosos, tricomas simples 1-1,8 mm compr., com base levemente alargada, eretos a adpressos. Folhas com pecíolos 0,9-2,8 cm compr.; lâmina 613,5 × 3-6,2 cm, membranácea a cartácea, oval, elíptica a lanceolada, ápice agudo a acuminado, margem lisa a denticulada, base obtusa a levemente cordada, nervuras 5 a $5+2$ basais a curtamente suprabasais; face adaxial densamente estrigosa, tricomas simples 0,8 1,8 $\mathrm{mm}$ compr., base levemente alargada, levemente adpressos, face abaxial esparsa a densamente pubescente a vilosa, tricomas simples 0,6-1 mm compr., base não alargada, sinuosos a enovelados, e moderadamente furfuráceo-estrelado. Panículas $8-26,5 \mathrm{~cm}$ compr.; brácteas 1,7-4 mm compr.; bractéolas 1,2-2,2 mm compr. Flores 5-meras; hipanto 4-5,7 mm compr.; cálice com tubo $0,3-0,5 \mathrm{~mm}$ compr., lacínias internas $0,5-0,8 \mathrm{~mm}$ compr., triangulares, lacínias externas $1,2-1,8 \mathrm{~mm}$ compr., lineares cilíndricas; pétalas 3-4,2 mm 
compr.; estames 10, conectivo inapendiculado ou extremamente curto, antera 2,2-3,6 mm compr., rósea; ovário 1,8-3 mm compr., 3locular, ápice com tricomas simples. Frutos 7$11 \times 5,5-9 \mathrm{~mm}, 130-150$ sementes, $0,7-1 \times$ 0,4-0,5 mm.

Material selecionado: Adrianópolis, 18.X.2005, fl., R. Goldenberg 755 (UPCB). Arapoti, 24.XI.2003, fr., E. Maieski 6(MBM). Balsa Nova, 16.X.2005, fl., R. Goldenberg 695 (UPCB). Bocaiúva do Sul, 5.XII.1978, fl., G Hatschbach 41914 (MBM). Campo Largo, 22.IX.1976, fl., L. Dombrowski 6428(MBM). Campo Mourão, 4.VII.2003, fl., M. Caxambu 60 (UPCB). Carambeí, 3.X.1964, fl., G. Hatschbach 11675 (MBM). Jaguariaíva, 24.V.2003, bot., A. Cervi 8415 (UPCB). Lapa, 13.VIII.1982, fl., H. Oliveira 608 (MBM). Piraí do Sul, 17.XI.1970, fl., G. Hatschbach 25432 (MBM). Ponta Grossa, 16.VIII.2005, fl., R. Goldenberg 691 (UPCB). Quatro Barras, 15.X.1995, fl., C. Roderjan 1226 (UPCB). Rio Branco do Sul, 14.X.1971, fl., L. Dombrowski 3653 (MBM). São Jerônimo da Serra, 27.V.2002, fl., K. de Sá 177 (FUEL, UPCB). Sengés, 27.V.1977, fl., G. Hatschabach 39940 (MBM). Telêmaco Borba, 17.X.1999, fl., A. Vieira 535 (FUEL). Tibagi, 6.XII.2007, fl., E. Camargo 168 (UPCB). Tomazina, 2.XI.1998, fl., G. Hatschbach 68300 (MBM). Ventania, 23.VII.2004, fl., D. Estevan 468(UPCB).

Distribuição: Bahia, Espírito Santo, Minas Gerais, Rio de Janeiro, São Paulo, Paraná e Rio Grande do Sul, sem citação para Santa Catarina (Wurdack 1962). No Paraná ocorre nos três planaltos, em FOM, CA, CE e transição FOM-FE.

Esta espécie possui diversidade morfológica considerável. Suas folhas são desde ovais e elípticas até lanceoladas, com indumento esparso a denso, e com consistência desde membranácea até cartácea. A maior parte do material examinado neste estudo estava identificada nos herbários como $L$. lacunosa Cogn. Segundo Cogniaux (18861888), L. lacunosa teria ramos e folhas estrigosos, face adaxial bulada e a abaxial foveolada, enquanto $L$. aurea seria caracterizada pelos ramos e folhas vilosos a pubescentes, com as faces adaxial e abaxial planas. Pela dificuldade encontrada na distinção entre estas duas espécies, e também pela ocorrência de vários indivíduos com características intermediárias entre estas citadas por Cogniaux, foi aceita uma única espécie para o estado, $L$. aurea, que é o nome mais antigo. É possível que estas espécies venham a ser sinonimizadas no futuro. Coletada com flores entre abril e dezembro, com frutos entre outubro e dezembro e em março.

3. Leandra australis (Cham.) Cogn. in Mart. \& Eichler, Fl. bras. 14(4): 104. 1886. Sect. Niangae.

Fig. 2e, $3 \mathrm{~h}$

Subarbustos a arbustos 0,5-3 m alt. Ramos jovens cilíndricos, moderado a densamente furfuráceo-estrelados e moderadamente estrigosos a hirsutos, tricomas simples 3-4,5 mm compr., com base levemente alargada, eretos. Folhas com pecíolos 0,8-2,4 cm compr.; lâmina 6,5-10,5 × 3-6 cm, membranácea, oval, ápice agudo a acuminado, margem denticulada, base obtusa a cordada, nervuras 5 a $5+2$ basais a curtamente suprabasais; face adaxial moderadamente estrigosa, tricomas simples 2-3,3 mm compr., base levemente alargada, levemente adpressos, face abaxial esparsa a moderadamente pubescente, tricomas simples 1,5-2 mm compr., base não alargada, sinuosos, e moderado a densamente furfuráceo-estrelado. Panículas 10,5-16,5 cm compr.; brácteas 2-4,3 mm compr.; bractéolas $0,8-1,5 \mathrm{~mm}$ compr. Flores 5-meras; hipanto 3,5-4,3 mm compr.; cálice com tubo 0,3-0,5 mm compr., lacínias internas 1-1,5 mm compr., triangulares, lacínias externas 2,3-3 mm compr., lineares; pétalas 3,3-4,3 mm compr.; estames 10, conectivo inapendiculado, antera 2,5-3,8 mm compr., amarela; ovário 1,8-2,6 mm compr., 3-locular, ápice glabro. Frutos 5-6 × 4-4,5 mm, 150300 sementes, $1-1,2 \times 0,5-0,7 \mathrm{~mm}$.

Material selecionado:Adrianópolis, 12.XII.2006, fl., E. Camargo 74 (UPCB). Antonina, 5.XII.1986, fl., A. Cervi, 2414 (UPCB). Bocaiúva do Sul, 25.XI.2006, fl., E. Camargo 43 (UPCB). Campina Grande do Sul, 17.X.2005, fl., R. Goldenberg 712 (UPCB). Castro, 25.XI.2003, fl., R. Moro s.n.(HUPG 10964). Colombo, 12.I.1984, bot., A. Bidá 252 (UPCB). Curitiba, 21.XI.2007, fl., E. Camargo 154 (UPCB). 


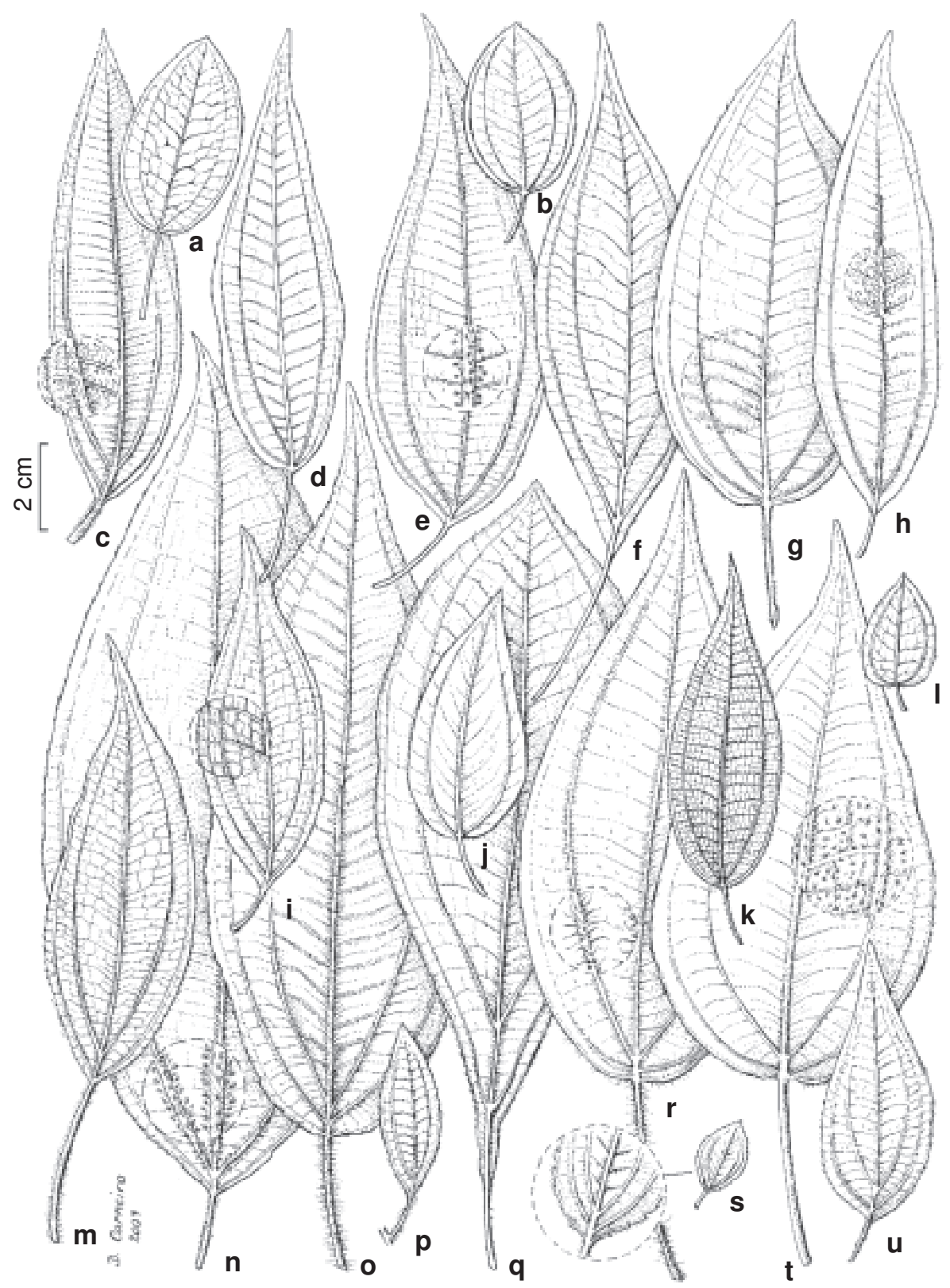

Figura 1 - Folhas de espécies de Leandra, seções Carassanae, Chaetodon, Niangae, Oxymeris e Secundiflorae que ocorrem no Paraná (face abaxial) - a. L. pallida (Goldenberg 794); b. L. humilis (Goldenberg 799); c. L. fallax (Camargo 98); d. L. glabrata (Silva 3177); e. L. carassana (Hatschbach 69826); f. L. laevigata (Labiak 1930); g. L. aurea (Goldenberg 755 ); h. L. purpurascens (Silva 4985); i. L. laxa (Caxambu UPCB 44805); j. L. riograndensis (Goldenberg UPCB 52085.); k. L. kleinii (Hatschbach 8556); 1. L. calvescens (Mocochisnki 277); m. L. refracta (Goldenberg 707); n. L. dasytricha (Iserrnhagen 215); o. L. xanthostachya (Goldenberg 738); p. L. itatiaiae (Goldenberg 801); q. L. longisetosa (Camargo 20); r. L. sp. (Hatschbach 10169); s. L. microphylla (Cervi 7062); t. L. tetraquetra (Camargo 138); u. L. debilis (Gatti 133).

Figure 1 - Leaves of Leandra, section Carassanae, Chaetodon, Niangae, Oxymeris and Secundiflorae in the state of Paraná (abaxial surface) - a. L. pallida (Goldenberg 794); b. L. humilis (Goldenberg 799); c. L. fallax (Camargo 98); d. L. glabrata (Silva 3177); e. L. carassana (Hatschbach 69826); f. L. laevigata (Labiak 1930); g. L. aurea (Goldenberg 755); h. L. purpurascens (Silva 4985); i. L. laxa (Caxambu UPCB 44805); j. L. riograndensis (Goldenberg UPCB 52085.); k. L. kleinii (Hatschbach 8556); 1. L. calvescens (Mocochisnki 277); m. L. refracta (Goldenberg 707); n. L. dasytricha (Iserrnhagen 215); o. L. xanthostachya (Goldenberg 738); p. L. itatiaiae (Goldenberg 801); q. L. longisetosa (Camargo 20); r. L. sp. (Hatschbach 10169); s. L. microphylla (Cervi 7062); t. L. tetraquetra (Camargo 138); u. L. debilis (Gatti 133). 
Guaraniaçú, 10.X.1986, fl., R. Negrelle 120(UPCB). Guaraqueçaba, 7.XII.1999, fr., G Gatti 556 (UPCB). Guaratuba, 2.XII.1996, fl., J. Silva 1792 (FUEL, MBM). Londrina, fr., 16.XI.1986, M. Tomori 9 (FUEL). Matinhos, 7.XI.2003, fr., M. Vieira 65 (UPCB). Morretes, 14.XII.2007, fl., E. Camargo 189 (UPCB). Piraquara, 13.X.2002, fl., P. Labiak 1925 (UPCB). Ponta Grossa, 28.III.2002, fr., R. Moro s.n. (HUPG 10778). Quatro Barras, 15.XII.1964, fl., G. Hatschbach 12025 (UPCB). Sapopema, 27.IX.1997, bot., C. Medri 882 (FUEL, UPCB). Telêmaco Borba, fr., 13.VI.1989, A. Vieira 322 (FUEL). Tibagi, 13.IX.1997, bot., L. Mostasso s.n. (FUEL 28906). Tijucas do Sul, 5.XII.2001, fl., D. Liebsch 393(UPCB). Ventania, 7.XII.2004, fl., D. Estevan 546 (UPCB).

Distribuição: Rio de Janeiro, São Paulo, Paraná, Santa Catarina e Rio Grande do Sul. No Paraná a espécie ocorre em todas as unidades geomorfológicas e formações vegetacionais.

As plantas de L. australis são subarbustos a arbustos pequenos, com folhas ovais de coloração verde escura característica, e venação basal ou curtamente suprabasal. As inflorescências possuem indumento vermelho escuro a nigrescente, e flores com anteras amarelas. Pode ser confundida com L. xanthocoma, que difere pelos estames maiores (anteras com até $5 \mathrm{~mm}$ compr., fig. 3i) e ovário com 4 lóculos. Alguns espécimes paranaenses estavam determinados como L. nianga Cogn., que ocorre em Minas Gerais, Espírito Santo, Rio de Janeiro e São Paulo e que difere de $L$. australis pelas das lacínias internas do cálice maiores que $2 \mathrm{~mm}$ compr. Coletada com flores e frutos em todos os meses do ano.

4. Leandra barbinervis (Cham. ex Triana) Cogn. in Mart. \& Eichler, Fl. bras. 14(4): 159. 1886. Sect. Oxymeris.

Fig. $2 \mathrm{~m}$

Arbustos a arvoretas, 1,5-7 m alt. Ramos jovens cilíndricos a levemente achatados, esparsamente furfuráceo-estrelados. Folhas com pecíolos 1,7-5 cm compr.; lâmina 10-28 $\times 4-13 \mathrm{~cm}$, cartácea, elíptica a obovada, ápice brevemente acuminado, margem lisa, base obtusa a cuneada, nervuras 5 basais, raro curtamente suprabasais; face adaxial glabra a furfurácea, face abaxial esparsamente furfurácea, tricomas simples ao longo da nervura principal. Panículas
8-14 cm compr.; brácteas $0,5-1,7 \mathrm{~mm}$ compr.; bractéolas $0,5-0,6 \mathrm{~mm}$ compr. Flores 5 -meras; hipanto 2-2,8 mm compr.; cálice com tubo 0,3$0,5 \mathrm{~mm}$ compr., lacínias internas $0,4-0,7 \mathrm{~mm}$ compr., triangulares, lacínias externas $0,5-1 \mathrm{~mm}$ compr., cilíndricas a lineares; pétalas $2-2,5 \mathrm{~mm}$ compr; estames 10, conectivo inapendiculado, antera 1,7-2,1 mm compr., alva; ovário 2-2,5 mm compr., 3-4-locular, ápice glabro. Frutos 4,57,5 $\times 4-7 \mathrm{~mm}, 400-500$ sementes, $0,8-1 \times$ $0,5-0,7 \mathrm{~mm}$.

Material selecionado: Bocaiúva do Sul, VI.1972, fl., G. Hatschbach 29759 (MBM). Campina Grande do Sul, IX.1996, fl., J. Silva 1718 (MBM). Morretes, 7.VIII.1986, fl. e fr., J. Cordeiro 340 (MBM, UPCB). Piraquara, 1.VIII.2004, fl. e fr., M. Reginato 19 (UPCB). Quatro Barras, 14.V.1987, fl. e fr., $R$. Kummrow 2914 (UPCB). Tunas do Paraná, 17.X.2005, fl. e fr., R. Goldenberg 741 (UPCB).

Distribuição: Minas Gerais, Rio de Janeiro, São Paulo, Paraná e Santa Catarina. No Paraná ocorre na Serra do Mar e Primeiro Planalto, em FD montana e submontana, transição FDFOM e FOM.

Esta espécie é reconhecida pelas folhas grandes (até $28 \mathrm{~cm}$ compr.), de consistência cartácea. As lâminas foliares possuem normalmente nervuras basais, com tricomas simples ao longo da nervura principal, na face abaxial. Ver comentários em L. acutiflora. Coletada com flores entre fevereiro e novembro, com frutos de maio a novembro.

5. Leandra calvescens (Triana) Cogn. in Mart. \& Eichler, Fl. bras. 14(4): 170. 1886. Sect. Chaetodon.

Fig. 11

Subarbustos 0,2-0,5 m alt. Ramos jovens achatados, esparso a moderadamente furfuráceo-estrelados. Folhas com pecíolos $0,2-1,5 \mathrm{~cm}$ compr.; lâmina $0,5-3,5 \times 0,2-0,8$ $\mathrm{cm}$, membranácea, oval, ápice agudo, margem lisa a levemente denticulada, base levemente cordada, nervuras 3 a $3+2$ basais; face adaxial glabra, face abaxial esparsamente furfuráceoestrelada, às vezes com projeções glandulares sésseis. Panículas 1,5-3cm; brácteas 1,3-2,5 mm compr.; bractéolas 1,3-2 mm compr. Flores 5-meras; hipanto 2-3,5 mm compr.; cálice com 


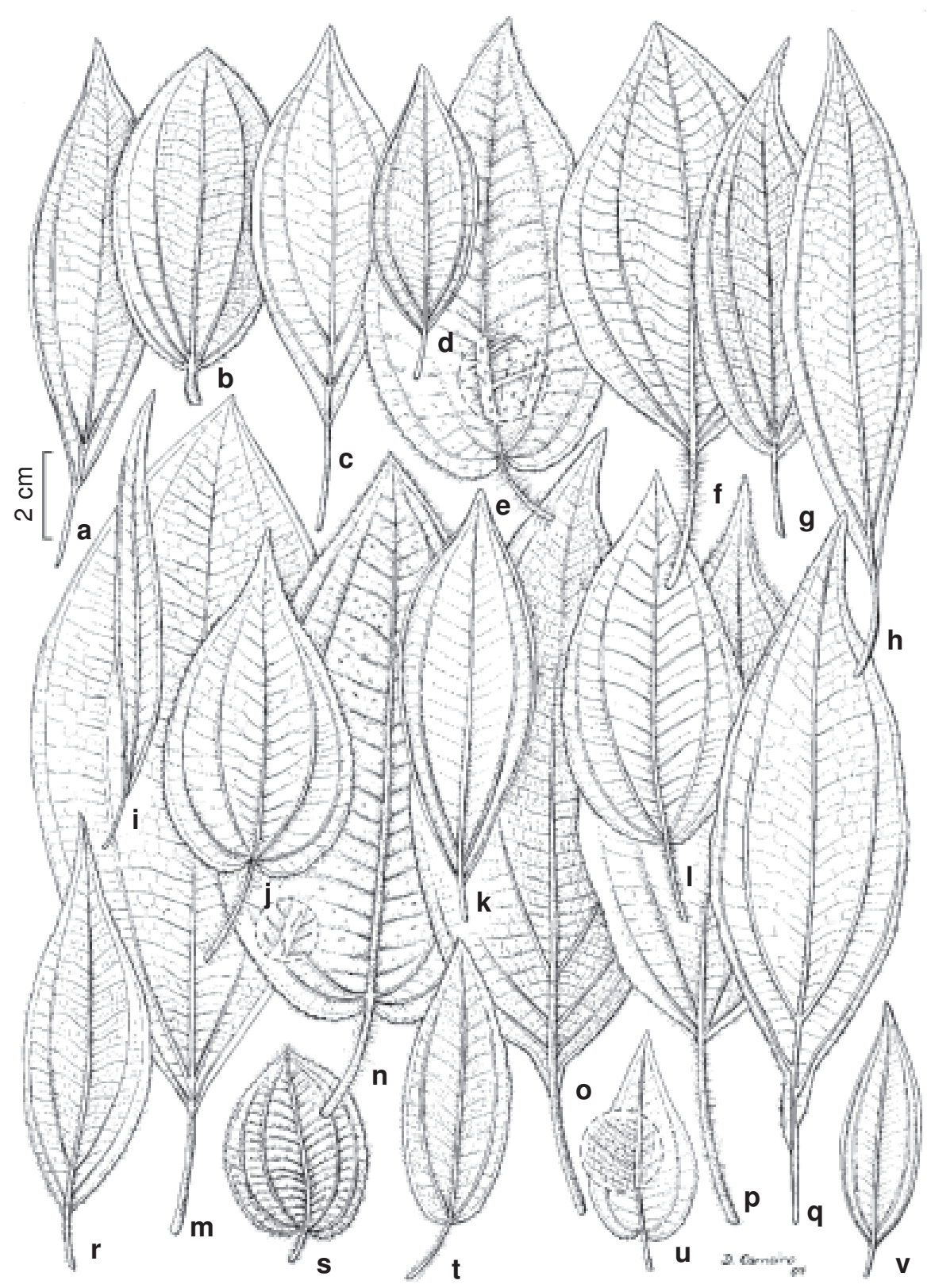

Figura 2 - Folhas de espécies de Leandra seções Carassanae, Chaetodon, Niangae, Oxymeris e Secundiflorae que ocorrem no Paraná (face abaxial) - a. L. reitzii (Pasdiora 67); b. L. polystachya (Hatschbach 5053); c. L. acutiflora (Isernhagen 327); d. L. sulfurea (Scheer 246); e. L. australis (Kozera 151); f. L. echinata (Goldenberg 743); g. L. hatschbachii (Goldenberg 796); h. L. pilonensis (Pasdiora 69); i. L. salicina (Goldenberg 501); j. L. cordifolia (Camargo 63); k. L. quinquedentata (Camargo 124 ); 1.L. xanthocoma (Camargo 40); m. L. barbinervis (Camargo 86); n. L. foveolata (Hatschbach 14654); o. L. regnellii (Labiak 1919); p. L. reversa (Camargo 145); q. L. gracilis (Camargo 62); r. L. ionopogon (J. Carneiro 1290); s. L. erostrata (Camargo 77); t. L. catharinensis (Hatschbach 46845); u. L. cordigera (Hatschbach 8447); v. L. neglecta (Cândido 5).

Figure 2 - Leaves of Leandra, section Carassanae, Chaetodon, Niangae, Oxymeris and Secundiflorae in the state of Paraná (abaxial surface) - a. L. reitzii (Pasdiora 67); b. L. polystachya (Hatschbach 5053); c. L. acutiflora (Isernhagen 327); d. L. sulfurea (Scheer 246); e. L. australis (Kozera 151); f. L. echinata (Goldenberg 743); g. L. hatschbachii (Goldenberg 796); h. L. pilonensis (Pasdiora 69); i. L. salicina (Goldenberg 501); j. L. cordifolia (Camargo 63); k. L. quinquedentata (Camargo 124); 1. L. xanthocoma (Camargo 40); m. L. barbinervis (Camargo 86); n. L. foveolata (Hatschbach 14654); o. L. regnellii (Labiak 1919); p. L. reversa (Camargo 145); q. L. gracilis (Camargo 62); r. L. ionopogon (J. Carneiro 1290); s. L. erostrata (Camargo 77); t. L. catharinensis (Hatschbach 46845); u. L. cordigera (Hatschbach 8447); v. L. neglecta (Cândido 5). 
tubo 0,2-0,3 mm compr., lacínias internas 0,4$0,6 \mathrm{~mm}$ compr., triangulares, lacínias externas 0,6-1 mm compr., lineares; pétalas 3-4 mm; estames 10 , conectivo inapendiculado, antera 1,3-1,8 mm compr., amarela; ovário 1,5-2 mm, 3-locular, ápice glabro. Frutos 4-5×3-3,5 mm, 50-90 sementes, 0,7-0,9 ×0,4-0,6 mm.

Material selecionado: Campina Grande do Sul, IV.2004, fl., A. Mocochinski 277 (MBM).

Material adicional: BRASIL, SANTA CATARINA: Campo Alegre, XI.1992, fl.,J. Cordeiro 916(MBM).

Distribuição: São Paulo, Paraná e Santa Catarina. No Paraná, é encontrada na Serra do Mar, em FD altomontana e montana.

Esta espécie pode ser reconhecida pelo pequeno porte (até $0,5 \mathrm{~m}$ alt.), com folhas ovais até $3,5 \mathrm{~cm}$, membranáceas, com a face adaxial glabra e a face abaxial furfuráceo-estrelada, e com projeções glandulares sésseis. Assemelha-se muito a L. pallida Cogn., que apresenta tricomas simples nos ramos das inflorescências e anteras alvas. Coletada com flores em novembro, dezembro e abril; com frutos entre fevereiro e abril.

6. Leandra carassana (DC.) Cogn. in Mart. \& Eichler, Fl. bras. 14(4): 120. 1886. Sect. Carassanae.

Fig. 1e

Subarbustos a arvoretas 1-4 m alt. Ramos jovens cilíndricos, moderado a densamente estrigoso-dendríticos, tricomas simples 0,8-1,5 mm compr., com base levemente alargada, eretos, mesclado com tricomas dendríticos, 0,7-2 mm compr., com eixo alargado. Folhas com pecíolos $0,8-4,5 \mathrm{~cm}$ compr.; lâmina 4,5-22 × 2,3-10,5 cm, cartácea, oval, elíptica a lanceolada, ápice acuminado, margem denticulada a denteada, base obtusa, cuneada a levemente cordada, nervuras 5 a $5+2$ basais a curtamente suprabasais; face adaxial moderadamente estrigosa, tricomas simples 0,8-1,5 mm compr., base levemente alargada, eretos, face abaxial com tricomas estrelado-estipitados, 0,4-0,8 mm compr., eixo não alargado. Panículas 5,5$17,5 \mathrm{~cm}$; brácteas 2,2-5 mm compr.; bractéolas 1,3-2,5 mm compr. Flores 5-meras; hipanto 3,2-4,2 mm compr.; cálice com tubo
0,3-0,5 mm compr., lacínias internas 0,7-1,3 mm compr., triangulares, lacínias externas 1,53,2 mm compr., lineares; pétalas 2,5-4,5 mm compr.; estames 10, conectivo inapendiculado, antera 2,5-4 mm compr., rósea; ovário 1,72,5 mm compr., 3-locular, ápice com tricomas simples. Frutos 6,5-8,2 × 4-8 mm, 100-250 sementes, 0,8-1 $\times 0,4-0,6 \mathrm{~mm}$.

Material Selecionado:Adrianópolis, 12.XII.2006, fr., E. Camargo 75 (UPCB). Apucarana, 1.X.1999, fl., D. Estevan 128 (FUEL). Balsa Nova, 16.X.2005, fl., R. Goldenberg 696 (UPCB). Bocaiúva do Sul, 25.XI.2006, fl., E. Camargo 45 (UPCB). Campina Grande do Sul, 22.X.1985, fl., Paciornik 182 (MBM). Campo Largo, 10.IV.1979, fl., L. Dombrowski 10455 (MBM). Colombo, 15.XII.2003, fr., R. Possette s.n. (UPCB 50470). Contenda, 17.XI.1972, bot., G. Hatschbach 30643 (MBM). Curitiba, 15.VII.2004, fr., G. Diógenes 8(UPCB). Dois Vizinhos, 11.VIII.1968, fl. e fr., G. Hatschbach 19389 (MBM). Dr. Ulysses, 3.XII.1999, fl., G. Hatschbach 69826 (MBM, UPCB). Guarapuava, 18.X.1973, fl., G. Hatschbach 32720 (MBM). Londrina, 24.V.1988, fr., M.Antunes s.n. (FUEL6418). Morretes, 10.I.1996, fl., O. Ribas 938(MBM). Palmas, 6.XII.1989, fl., G. Hatschbach 53666 (MBM). Palmeira, 10.IX.1989, fl., L. Dombrowski 13839 (MBM). Paranaguá, 12.IV.1948, fl., G Tessmann 3078 (MBM). Piraquara, 1.IV.2006, fl.,E. Camargo 11(UPCB). Ponta Grossa, 13.II.1949, bot., A. Brade 19531 (MBM, RB). Porto Vitória, 8.XII.1971, bot., G. Hatschbach 28394 (MBM). Quatro Barras, 5.IX.2006, fr., E. Camargo 36 (UPCB). Rio Branco do Sul, 11.X.1996, fl., A. Svolenski 309 (MBM). Santo Antonio do Paraíso, 25.IX.1997, bot., L. Demarchi s.n.(FUEL 28838). São José dos Pinhais, 1.IX.1994, fl., C. Poliquese 235 (MBM). São Mateus do Sul, 22.IV.1986, bot., $R$. Britez 527 (MBM). Tunas do Paraná, 21.IV.2007, fl., E. Camargo 96 (UPCB).

Distribuição: Bahia, Espírito Santo, Minas Gerais, Rio de Janeiro, São Paulo, Paraná, Santa Catarina e Rio Grande do Sul. No Paraná ocorre em todas as unidades geomorfológicas, desde FD até transição FOM-FE.

Esta espécie apresenta grande diversidade morfológica, e pode ser reconhecida pelos ramos cilíndricos, folhas com margem denticulada a denteada e face abaxial com a superfície recoberta por tricomas estrelado-estipitados. Assemelha-se muito a Leandra tetraquetra 
pela morfologia das folhas, que difere pelas folhas com face adaxial escabrosa e pelos ramos quadrangulares. Pode ser confundida também com $L$. dasytricha, que possui flores com dimensões de lacínias do cálice e anteras menores. Vários espécimes examinados nos herbários, também estavam identificados como L. dispar Cogn. e L. sublanata Cogn. Para Cogniaux (1886-1888), L. dispar possuiria ramos estrelado-furfuráceos, folhas com base levemente cordada e hipanto com indumento curto, enquanto $L$. sublanata possuiria ramos com tricomas estrelado-estipitados, folhas com base obtusa a atenuada e hipanto com indumento longo. Por fim, Leandra carassana diferiria de ambas pelas folhas de tamanhos iguais no par. Souza \& Baumgratz (2004) sinonimizaram $L$. sublanata a $L$. carassana. Não foi possível a distinção entre $L$. dispar e $L$. carassana, visto que foram encontrados espécimes com características intermediárias. Para o Paraná, portanto, foi aceito o nome mais antigo. Coletada com flores e frutos em praticamente todos os meses do ano.

7. Leandra catharinensis Cogn. in A. DC. \& C. DC., Monogr. Phan. 7: 1188. 1891. Sect. Chaetodon.

Fig. $2 \mathrm{t}$

Subarbustos a arbustos, $0,5-1 \mathrm{~m}$ alt. Ramos jovens levemente achatados, esparsamente furfuráceo-estrelados e esparso a densamente pubescentes, tricomas simples 0,7-1,4 mm compr., com base não alargada, sinuosos. Folhas com pecíolos $0,5-1,8 \mathrm{~cm}$ compr.; lâmina 2,5-9 × 1-3 cm, cartácea, lanceolada ou oval-lanceolada, ápice agudo a acuminado, margem denticulada, base cuneada a obtusa, nervuras 3 a $3+2$ basais; face adaxial moderada a densamente estrigosa, tricomas simples 0,6-1 mm compr., base levemente alargada, levemente adpressos, e esparsamente furfuráceo-estrelada; face abaxial densamente pubescente, tricomas simples $0,4-0,9 \mathrm{~mm}$ compr., base não alargada, sinuosos, e esparsamente furfuráceo-estrelada. Panículas 1-4,5 cm compr.; brácteas $1-3,5 \mathrm{~mm}$ compr.; bractéolas $0,8-1,8 \mathrm{~mm}$ compr. Flores 5-6- meras; hipanto 2-3 mm compr.; cálice com tubo $0,2-0,3 \mathrm{~mm}$ compr., lacínias internas $0,3-$ 0,7 mm compr., oblongas, lacínias externas $0,5-$ $1,2 \mathrm{~mm}$ compr., cilíndricas; pétalas $1,7-3 \mathrm{~mm}$ compr.; estames 10-12, conectivo com apêndice curto, antera 1,5-2,2 $\mathrm{mm}$ compr., alva; ovário 1,5-2,5 mm, 3-4-locular, ápice com tricomas simples. Frutos 3,5-4,5 × 3-4 $\mathrm{mm}$, sementes $0,6-0,8 \times 0,3-0,4 \mathrm{~mm}$.

Material selecionado: Curitiba, 21.XI.2007, fl., $E$. Camargo 150 (UPCB, MBM). General Carneiro, XI.1972, fl., G Hatschbach 30708 (MBM).

Material adicional: BRASIL, SANTA CATARINA: Urubici, XII.2000, fl. e fr., G. Hatschbach 71629 (MBM). RIO GRANDE DO SUL, Bom Jesus, XI.2001, fl., G Hatschbach 72659 (MBM). Cambará do Sul, II.1990, fl. e fr., M. Sobral 6153 (UPCB).

Distribuição: Paraná, Santa Catarina e Rio Grande do Sul. No Paraná, ocorre no Primeiro e Terceiro Planaltos, em FOM e transição FOM-FE. Wurdack (1962) citou esta espécie como endêmica de Santa Catarina.

Leandra catharinensis pode ser reconhecida pelas folhas lanceoladas ou ovallanceoladas, cartáceas, com 3 a 3+2 nervuras basais. As folhas possuem indumento furfuráceo-estrelado nas faces abaxial e adaxial, as inflorescências são pequenas (chegam a $4,5 \mathrm{~cm}$ compr.), possuem tricomas avermelhados, e podem ser encontradas nas posições terminais e laterais com a mesma frequência. Coletada com flores entre outubro e fevereiro, com frutos entre dezembro e março.

8. Leandra cordifolia (Naudin) Cogn. in Mart. \& Eichler, Fl. bras. 14(4): 98. 1886. Sect. Niangae. Fig. $2 \mathrm{j}$, e $3 \mathrm{~g}$

Subarbustos a arbustos, $0,5-1,5 \mathrm{~m}$ alt. Ramos jovens cilíndricos, moderado a densamente glanduloso-pubescentes, tricomas simples 2,5-3,5 mm compr., com base não alargada, sinuosos. Folhas com pecíolos 1,55,5 cm compr.; lâmina 4,8-8,5 × 3-6,5 cm, membranácea, oval, ápice acuminado, raro agudo, margem denticulada, base cordada, nervuras $5+2$ basais; ambas as faces moderada a densamente glanduloso-pubescente tricomas simples 1-2,8 mm compr., base não alargada, 
sinuosos, com glândula apical. Panículas 4,513 cm compr.; brácteas 1,7-3,2 mm compr.; bractéolas 0,5-0,7 mm compr. Flores 5-meras; hipanto 2,5-3,7 mm compr.; cálice com tubo 0,2-0,3 mm compr., lacínias internas $0,6-0,8$ $\mathrm{mm}$ compr., triangulares a lineares, lacínias externas 1-1,8 mm compr., lineares; pétalas 2,8-3,5 mm compr.; estames 10 , conectivo com apêndice dorsal curto ou ausente, antera 22,5 mm compr., alva; ovário 1,8-2,5 mm compr., 3-locular, ápice glabro. Frutos 6,5-7,5 $\times 5,6-6,8 \mathrm{~mm}, 130-150$ sementes, $0,7-0,9 \times$ 0,4-0,5 mm.

Material selecionado:Adrianópolis, 12.XII.2006, fl., E. Camargo 63(UPCB). Antonina, 20.XI.1998, fr., G. Hatschbach 68852 (UPCB). Campina Grande do Sul, 17.X.2005, fl. e fr., R. Goldenberg 708 (UPCB). Dr. Ulysses, 3.XII.1999, fl. e fr., G Hatschbach 69840 (UPCB). Guaraqueçaba, 20.XI.1974, fr., G. Hatschbach 35501 (MBM). Paranaguá, 26.IX.1987, bot., R. Britez 1793 (FUEL, MBM). Pontal do Paraná, 25.IX.1967, fl., G. Hatschbach 17226 (MBM). Quatro Barras, 15.XII.1964, bot., G. Hatschbach 12034 (MBM).

Distribuição: São Paulo, Paraná e Santa Catarina. No Paraná ocorre no Litoral, Serra do Mar e Primeiro Planalto, em FD e FOM.

Leandra cordifolia pode ser reconhecida pelas folhas ovais com base cordada e pelos tricomas glandulares avermelhados presentes nos ramos e folhas. As pétalas e anteras são alvas, e o estilete alvo-rosado. Coletada com flores entre julho e dezembro, com frutos entre outubro e dezembro.

9. Leandra cordigera (Triana) Cogn. in Mart. \& Eichler, Fl. bras. 14(4): 166. 1886. Sect. Chaetodon. Fig. $2 \mathrm{u}$

Subarbustos a arbustos 0,7-1 $\mathrm{m}$ alt. Ramos jovens cilíndricos, moderado a densamente furfuráceo-estrelados e moderadamente glanduloso-pubescentes, tricomas simples 0,30,7 mm compr., com base não alargada, sinuosos. Folhas com pecíolos 0,3-1,7 cm compr.; lâmina 2-4,8 × 1,2-3 cm, cartácea, oval, ápice acuminado, margem denticulada, base cordada, $3+2$ nervuras basais; faces adaxial e abaxial esparso a moderadamente glanduloso-pubescente, tricomas simples 0,3-
1 mm compr., base não alargada, sinuosos, glândula apical, e moderadamente furfuráceoestrelado. Panículas 1,7-6 cm compr.; brácteas 1-2,5 mm compr., bractéolas 1-2 mm compr. Flores 5-meras; hipanto 1,5-3,2 mm compr.; cálice com tubo 0,2-0,4 mm compr., lacínias internas 0,6-1 mm compr., estreitamente triangulares, lacínias externas $1-1,5 \mathrm{~mm}$ compr., lineares; pétalas 2-3,2 mm compr.; estames 10, conectivo inapendiculado, antera 1-1,5 mm compr; ovário 1,5-2,3 mm compr., 3-locular, ápice com tricomas simples. Frutos $3-3,5 \times 2,5-3,5 \mathrm{~mm}, 60-120$ sementes, $0,8-1$ $\times 0,5-0,6 \mathrm{~mm}$.

Material selecionado: Balsa Nova, 5.XI.1980, fl., G Hatschbach 43333 (MBM). Campo Largo, 20.XI.1983, fl., R. Kummrow 2401 (MBM). Guarapuava, 3.X.1969, bot., G. Hatschbach 22521 (MBM). Guaratuba, 7.II.2000, fl., J. Cordeiro 3263 (MBM). Jaguariaíva, 26.XI.1970, fl., G Hatschbach 25495 (MBM). Morretes, XI.2002, fl., M. Scheer 660 (MBM). Palmeira, XI.1962, fl., G. Hatschbach 11092 (MBM). São José dos Pinhais, 5.X.1997, fl., C. Poliquesi 2111 (MBM). Tijucas do Sul, X.1977, fl., G. Hatschbach 40460 (MBM).

Distribuição: Minas Gerais, Rio de Janeiro, São Paulo, Paraná e Santa Catarina. No Paraná, ocorre desde a Serra do Mar até o Terceiro Planalto paranaense, e desde a FD até transição FOM-FE.

Esta espécie pode ser reconhecida pelos ramos e folhas com indumento glandulosopubescente e furfuráceo-estrelado, folhas pequenas (2-4,8 cm compr.), ovais, com a base cordada. Coletada com flores entre outubro e fevereiro, com frutos em março.

10. Leandra dasytricha (A.Gray) Cogn. in Mart. \& Eichler, Fl. bras. 14(4): 113. 1886. Sect. Carassanae.

Fig. 1n

Arbustos a árvores 1-5 m alt. Ramos jovens cilíndricos, densamente estrigosodendríticos, tricomas simples $0,5-0,8 \mathrm{~mm}$ compr., com base levemente alargada, eretos, mesclados com tricomas dendríticos 0,5-0,8 $\mathrm{mm}$ compr., com eixo alargado. Folhas com pecíolos 1,6-2,6 cm compr.; lâmina 7,5-22 × 3-8,5 cm, membranácea, elíptica a oval, menos frequentemente oval-lanceolada, ápice 

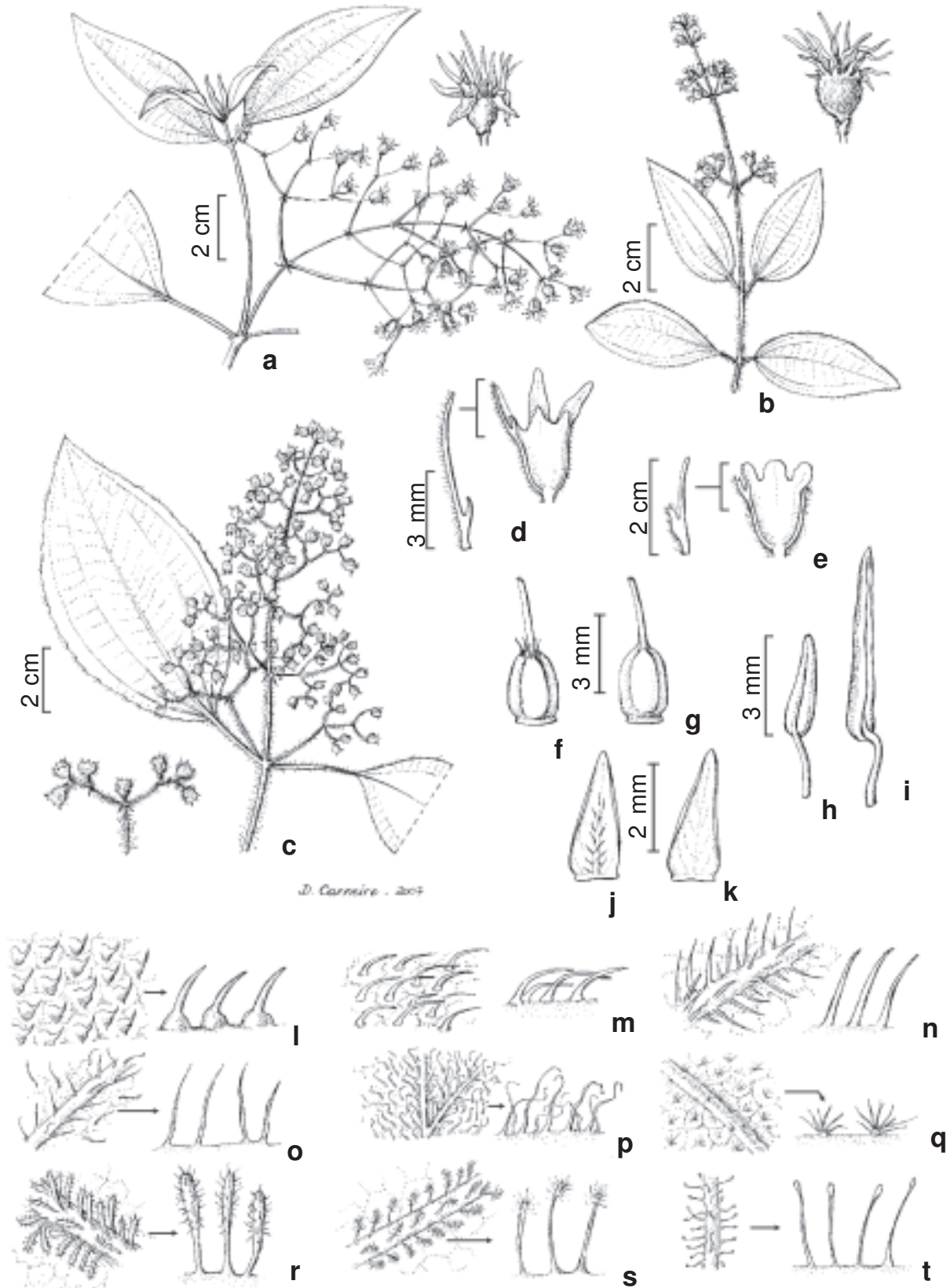

Figura 3 - Inflorescências, lacínias do cálice, ovários, estames, pétalas e indumento de espécies de Leandra, seções Carassanae, Chaetodon, Niangae, Oxymeris e Secundiflorae que ocorrem no Paraná - a. inflorescência e flor de L. laevigata (Lacerda 263); b. inflorescência e flor de L. polystachya (Hatschbach 11655); c. inflorescência e flor de L. reversa (Gatti 240); d. lacínias do cálice de L. ionopogon(Silva 1289); e. lacínias do cálice de L. xanthostachya (Camargo 72); f. ovário de L. erostrata (Ribas 3952); g. ovário de L. cordifolia (Hatschbach 32682); h. estame de L. australis (Camargo 85); i. estame de L. xanthocoma (Camargo 39); j. pétala de L. neglecta (Cervi 8314); k. pétala deL. tetraquetra (Goldenberg 807). Indumento-1. escabroso; m. estrigoso; n. hirsuto; o. pubescente; p. viloso; q. estrelado; r. dendrítico; s. estrelado estipitado; t. glandular.

Figure 3 - Inflorescence, calyx teeth, ovaries, stamens, petals and trichomes of Leandra section Carassanae, Chaetodon, Niangae, Oxymeris and Secundiflorae in the state of Paraná - a. inflorescence and flower of L. laevigata (Lacerda 263); b. inflorescence and flower of L. polystachya (Hatschbach 11655); c. inflorescence and flower of L. reversa (Gatti 240); d. calyx teeth of L. ionopogon (Silva 1289); e. calyx teeth of $L$. xanthostachya (Camargo 72); f. ovary of $L$. erostrata (Ribas 3952); g. ovary of $L$. cordifolia (Hatschbach 32682); h. stamen of L. australis (Camargo 85); i. stamen of L. xanthocoma (Camargo 39); j. petal of L. neglecta (Cervi 8314); k. petal of L. tetraquetra (Goldenberg 807). Trichomes - 1. scabrous; m. strigose; n. hirsute; o. pubescent; p. villose; q. stellate; r. dendritic; s. stipitate-stellate; t. glandulose. 
acuminado, margem levemente denticulada, base cuneada a obtusa, nervuras $5+2$ basais a curtamente suprabasais; face adaxial moderadamente estrigosa, tricomas simples 0,7-1,2 mm compr., base levemente alargada, levemente adpressos, face abaxial com indumento pubescente-dendrítico, tricomas simples 0,6-1 mm compr., base não alargada, sinuosos, mesclados com tricomas dendríticos, 0,5-1 mm compr., eixo alargado. Panículas 6,5-10 cm compr.; brácteas 0,7-1 mm compr.; bractéolas 0,7-1 mm compr. Flores 5-meras; hipanto 2,3-3,6 mm compr.; cálice com tubo 0,2-0,3 mm compr., lacínias internas $0,3-0,5$ mm compr., triangulares, lacínias externas $0,7-$ 1,2 mm compr., lineares; pétalas 2,2-3 mm compr.; estames 10, conectivo inapendiculado, antera 1,4-1,8 mm compr., alva; ovário 1,52,2 mm compr., 3-locular, ápice com tricomas simples. Frutos 4,5-5,5 ×3,8-4,5 mm, 200300 sementes, $0,6-0,7 \times 0,3-0,4 \mathrm{~mm}$.

Material selecionado:Adrianópolis, 12.XII.2006, fl., E. Camargo 76(UPCB). Antonina, 26.VI.2007, fr., E. Camargo 130 (UPCB). Bocaiúva do Sul, 22.IV.2007, fr., E. Camargo 115 (UPCB). Campina Grande do Sul, 17.X.2005, bot., R. Goldenberg 709 (UPCB). Cerro Azul, 16.XII.1992, fl., G. Hatschbach 58452 (MBM). Guaraqueçaba, 13.IV.2002, fr., $G$. Gatti s.n. (MBM 275897). Guaratuba, 22.III.1972, fr., G. Hatschbach 29349 (MBM). Matinhos, 3.I.1967, J. Lindemann 3842 (RB). Morretes, 14.XII.2007, fl., E. Camargo 182(UPCB). Paranaguá, 12.II.1965, bot., G. Hatschbach 12369 (MBM). São José dos Pinhais, 5.VI.1986, fr., J. Motta 306 (MBM). Distribuição: Bahia, Espírito Santo, Rio de Janeiro, São Paulo, Paraná, Santa Catarina e Rio Grande do Sul. No Paraná, ocorre no Litoral, Serra do Mar e Primeiro Planalto, em FD (Terras Baixas, Submontana e Montana) e FOM respectivamente.

Esta espécie atinge até $5 \mathrm{~m}$ de altura e as folhas normalmente são grandes, com indumento pubescente-dendrítico na face abaxial. As flores são menores que em L. carassana (raramente atingem 3,6 $\mathrm{mm}$ ), as pétalas e estames alvos, e o estilete róseo. No litoral, as plantas geralmente possuem folhas maiores em relação aos espécimes que ocorrem no planalto (ver comentários em L. carassana). Coletada com flores entre outubro e fevereiro, com frutos entre março e agosto.

11. Leandra debilis (Naudin) Cogn. in Mart. \& Eichler, Fl. bras. 14(4): 174. 1886. Sect. Chaetodon.

Fig. $1 \mathrm{u}$

Subarbustos a arbustos 0,2-1 m alt. Ramos jovens cilíndricos, esparsamente furfuráceoestrelados e moderadamente pubescentes ou não, no primeiro caso com tricoma simples 0,4 $2 \mathrm{~mm}$ compr., com base não alargada, sinuosos. Folhas com pecíolos 0,3-3,3 cm compr.; lâmina 2,5-8 × 1-3,5 cm, membranácea, elíptica, ápice acuminado, margem lisa, base cuneada a obtusa, 3+2 nervuras suprabasais; face adaxial esparsamente estrigosa, às vezes ausente, tricomas simples 0,4-2 mm compr., base levemente alargada, levemente adpressos, e moderadamente furfuráceo-estrelado, face abaxial densamente pubescente, às vezes ausente, tricomas simples 0,4-1,5 mm compr., base não alargada, sinuosos, e densamente furfuráceo-estrelado. Panículas 1,5-7 cm compr.; brácteas 1-5 mm compr; bractéolas 0,5-1,5 mm compr. Flores 5-6-meras; hipanto 1,5-3,8 mm compr.; cálice com tubo 0,1-0,2 mm compr., lacínias internas 0,2-0,5 mm compr., ovais, lacínias externas 0,4-0,8 mm compr., triangulares; pétalas 1,8$3 \mathrm{~mm}$; estames $10(-12)$, conectivo inapendiculado, antera 0,8-1,3 mm compr.; ovário 1-2 mm compr., 3-locular, ápice com tricomas estrelados. Frutos 2,5-4,2 ×2,7-3,5 mm, 170400 sementes, $0,4-0,7 \times 0,2-0,4 \mathrm{~mm}$.

Material selecionado: Almirante Tamandaré, 12.I.1996, fr., O. Ribas 1077 (MBM). Balsa Nova, X.1973, fl., G. Hatschbach 32946 (MBM). Campo Largo, XI.1961, fl., G. Hatschbach 8782 (MBM). Colombo, XII.1983, fl. e fr., A. Bidá 131 (UPCB). Curitiba, X.1973, bot., L. Dombrowski 4860 (MBM). General Carneiro, XII.1971, fl., G. Hatschbach 28323 (MBM). Guaratuba, XI.1958, bot. e fl., G. Hatschbach 5260 (MBM). Ipiranga, XI.1957, fl., G. Hatschbach 4268 (MBM). Jaguariaíva, II.1970, fl., G Hatschbach 25499 (MBM, UPCB). Morretes, XII.1959, fl., G. Hatschbach 6807 (MBM). Palmeira, XI.2004, fl., $M$. Caxambu 677 (UPCB). Piraquara, XI.2001, bot., e f1., M. Caxambu s.n. (UPCB 41917). Ponta Grossa, XI.1989, fl., A. Cervi 3017 (MBM, UPCB). Quatro Barras, XII.1996, fl. e fr., G. Gatti 133 (UPCB). São 
José dos Pinhais, XII.1995, fl., G. Hatschbach 63999 (MBM). Tijucas do Sul, XII.1976, fl., R. Kummrow 1187(MBM). Tunas do Paraná, XI.1998, fl., L. Abe 2604 (MBM).

Distribuição: Minas Gerais, Rio de Janeiro, São Paulo, Paraná e Santa Catarina. No Paraná, ocorre nos três planaltos, em FOM, CA, CE e transição FOM-FE.

Esta espécie apresenta grande variação morfológica. Os ramos e folhas podem ou não apresentar indumento e as folhas variam de elípticas a ovais. A distinção em relação a $L$. hirtella é complicada. Cogniaux (1886-1888) distinguiu L. hirtella pelas folhas lanceoladas, com nervuras suprabasais e pecíolo longo, enquanto L. debilis teria folhas largas, com nervuras basais, base obtusa e brevemente peciolada. Vários espécimes com características intermediárias foram observadas, e desta forma foi aceita para o Paraná apenas uma espécie, sendo utilizado o nome mais antigo. Wurdack (1962) sugeriu a sinonimização destas espécies. Coletada com flores entre outubro e fevereiro, com frutos entre dezembro e abril.

12. Leandra echinata Cogn in Mart. \& Eichler, Fl. bras. 14(4): 607. 1886. Sect. Niangae. Fig. $2 f$

Arbustos 1-3 m alt. Ramos jovens tri a quadri-sulcados, densamente hirsutos, tricomas simples 3-6,5 mm compr., com base levemente alargada, eretos. Folhas com pecíolos 1,7-7,5 cm compr.; lâmina 7-11,5× 3,7-8 cm, membranácea, elíptica, oval a obovada, ápice agudo, margem lisa, base cuneada a obtusa, nervuras $5+2$ basais; face adaxial glabra, face abaxial glabra ou esparsamente hirsuta, tricomas simples 1,33,8 mm compr., base levemente alargada, eretos. Panículas 6,5-13 cm compr.; brácteas 1-1,4 mm compr.; bractéolas 0,5-0,7 mm compr. Flores 5-meras; hipanto 3-5 mm compr.; cálice com tubo $0,3-0,4 \mathrm{~mm}$ compr., lacínias internas 1,5-2,5 mm compr., lacínias externas 1,6-2,8 mm compr., lineares; pétalas $3,2-5,8 \mathrm{~mm}$ compr.; estames 10 , conectivo inapendiculado, antera 2,3-3,3 $\mathrm{mm}$ compr., alva; ovário 2-3 mm compr., 5-locular, ápice glabro. Frutos 5,5-7,5 $\times 4,5-6,5 \mathrm{~mm}, 250$ sementes, $0,6-0,8 \times 0,4-0,5 \mathrm{~mm}$.

Material selecionado: Adrianópolis, 12.XII.2006, fr., E. Camargo 69 (UPCB). Antonina, 3.VII.1969, fl., G. Hatschbach 21682 (UPCB). Bocaiúva do Sul, 1.IX.1994, fl., J. Silva 1392 (MBM). Campina Grande do Sul, 17.X.2005, R. Goldenberg 706 (UPCB). Cerro Azul, 3.VII.1960, fl., G Hatschbach 7104 (UPCB). Guaraqueçaba, 10.V.2002, fr., M. Scheer 388(MBM). São José dos Pinhais, 22.XII.1987, fr., J. Silva 450 (UPCB). Tunas do Paraná, 17.X.2005, fl., $R$. Goldenberg 743 (UPCB).

Distribuição: São Paulo, Paraná e Santa Catarina. No Paraná ocorre no Litoral e Serra do Mar (FD), e da região do Vale do Ribeira, no Primeiro Planalto, área de transição FD-FOM.

Leandra echinata pode ser reconhecida pelas folhas ovais ou obovadas, glabras na face adaxial, e pelos ramos com indumento hirsuto, de coloração alvo-amarelada característica. Coletada com flores entre junho e novembro, com frutos em maio, novembro e dezembro.

13. Leandra erostrata (DC.) Cogn. in Mart. \& Eichler, Fl. bras. 14(4): 139. 1886. Sect. Carassanae.

Fig. $2 \mathrm{~s}, 3 \mathrm{f}$

Subarbustos a arbustos $0,4-1 \mathrm{~m}$ alt. Ramos jovens cilíndricos, moderadamente furfuráceo-estrelados e densamente estrigosos, tricomas simples 1,3-2 mm compr., com base levemente alargada, eretos a sinuosos. Folhas com pecíolos 0,2-0,4 cm compr.; lâmina 3$5,5 \times 2,5-4 \mathrm{~cm}$, cartácea, orbicular a oval, ápice apiculado a arredondado, margem denticulada, base cordada, nervuras 5 a $5+2$ basais; face adaxial densamente estrigosa, tricomas simples 1-1,6 mm compr., base levemente alargada, levemente adpressos, e moderadamente furfurácea-estrelada; face abaxial densamente pubescente, tricomas simples 1-1,6 mm compr., base não alargada, sinuosos, e densamente furfuráceo-estrelado. Panículas 5-7 cm compr.; brácteas 3-5 mm compr.; bractéolas 2,5-3,5 mm compr. Flores 5-meras; hipanto 2,7-4 mm compr.; cálice com tubo $0,3-0,4 \mathrm{~mm}$ compr., lacínias internas $0,5-$ $0,8 \mathrm{~mm}$ compr., triangulares, lacínias externas 1,5-2 mm compr., lineares; pétalas 2,5-3,5 mm compr.; estames 10, conectivo inapendiculado, 
antera 2-2,3 mm compr., rósea; ovário 2-2,5 $\times 1,2-1,5 \mathrm{~mm}, 3$-locular, ápice com tricomas simples. Frutos 4,5-5,5 × 4-4,5 mm, 250-300 sementes, 0,6-0,7 ×0,3-0,4 mm.

Material selecionado:Adrianópolis, 12.XII.2006, fl., E. Camargo 77 (UPCB). Araucária, 24.I.1965, bot., M.L.P 302 (MBM). Balsa Nova, 6.XII.1979, bot., L. Dombrowski 10792 (MBM). Bocaiúva do Sul, 30.I.1996, fl., O. Ribas 1099 (MBM). Campina Grande do Sul, 13.XI.1958, fl., G. Hatschbach 5199 (MBM). Campo Largo, 10.I.1977, fl., L. Dombrowski 6944 (MBM). Colombo, 24.I.1968, bot., G. Hatschbach 18417 (MBM). Curitiba, 21.XI.2007, bot. e fl., E. Camargo 152 (MBM). Ipiranga, 20.XII.1970, fl., G. Hatschbach 25895 (MBM). Itaperuçu, 29.XI.1964, fl., L. Dombrowski 999 (MBM). Jaguariaíva, 17.XII.1991, fl., A. Cervi 3537 (MBM, UPCB). Lapa, 2.III.2002, fr., J. Cordeiro 1968 (MBM). Palmas, 4.XII.1971, fl., G. Hatshbach 28159 (HBR, MBM). Palmeira, 7.XI.2004, fl., $M$. Caxambu 633 (UPCB). Ponta Grossa, 12.X.1995, fl., C. Poliquese 447(MBM). Tibagi, 6.XII.2007, fl., E. Camargo 174 (UPCB). Tijucas do Sul, 15.XII.1997, bot., Ribas 2143(MBM).

Distribuição: Minas Gerais, Rio de Janeiro, São Paulo, Paraná, Santa Catarina e Rio Grande do Sul. Há registro de ocorrência no Alto Amazonas (Cogniaux 1886-1888) em região de Campo, mas Wurdack (1962) não cita este estado como área de ocorrência. No Paraná ocorre nos 3 planaltos, em FOM, CA e CE.

Esta espécie pode ser reconhecida pelo porte pequeno, e folhas cartáceas com pecíolos reduzidos e lâminas orbiculares a ovais, com indumento estrigoso e furfuráceo-estrelado na face adaxial. Leandra erostrata é semelhante a L. polystachya, que difere pela ausência de indumento furfuráceo-estrelado na face adaxial da lâmina, e pelo tamanho maior das folhas e inflorescências. Coletada com flores entre outubro e março, com frutos entre janeiro e março.

14. Leandra fallax (Cham.) Cogn. in Mart. \& Eichler, Fl. bras. 14(4): 125. 1886. Sect. Carassanae.

Fig. 1c

Arbustos 1,5-3 m alt. Ramos jovens cilíndricos, esparsamente furfuráceo-estrelados e moderada a densamente estrigosos, tricomas simples 1-1,3 mm compr., com base levemente alargada, eretos. Folhas com pecíolos 1-2,6 cm compr.; lâmina 7,5-12 ×2-4,5 cm, cartácea, lanceolada, ápice acuminado, margem lisa a levemente denticulada, base cuneada, nervuras $3+2$ a $5+2$ suprabasais; face adaxial moderadamente estrigosa, tricomas simples $0,6-1 \mathrm{~mm}$ compr., base levemente alargada, eretos, face abaxial densamente vilosa, tricomas simples $0,6-0,8 \mathrm{~mm}$ compr., base não alargada, enovelados. Panículas 5,5-15 cm compr.; brácteas 1-2,2 mm compr., bractéolas 1-2,2 mm compr. Flores 5meras; hipanto 2,5-4,7 mm compr; cálice com tubo 0,3-0,4 mm compr., lacínias internas 0,7$1 \mathrm{~mm}$ compr., triangulares, lacínias externas 1-2,2 mm compr., lineares; pétalas 2-2,6 mm compr.; estames 10, conectivo inapendiculado, antera 2-2,3 mm compr., rósea; ovário 1,7-2 mm compr., 3-locular, ápice com tricomas simples. Frutos 5-7,5 × 5-6,5 mm, 20 sementes, 0,6$0,8 \times 0,4-0,5 \mathrm{~mm}$.

Material selecionado: Antonina, 26.VI.2007, E. Camargo 137 (UPCB). Campo Largo, 21.IX.1979, bot., L. Dombrowski 10706 (MBM). Bocaiúva do Sul, 28.XII.1994, bot., G Hatschbach 61389 (MBM). Morretes, 11.I.1949, fl., G. Tessmann 3756 (MBM). Palmeira, 22.XI.1989, bot., L. Dombrowski 14147 (MBM). Tunas do Paraná, 21.IV.2007, fr., E. Camargo 98 (UPCB).

Distribuição: Minas Gerais, Espírito Santo, Rio de Janeiro, São Paulo, Paraná e Santa Catarina. No Paraná, ocorre no Litoral, Serra do Mar, Primeiro e Segundos Planaltos, em FD, FOM e CA.

Pode ser reconhecida pelas folhas lanceoladas, com indumento viloso na face abaxial. Assemelha-se a L. purpurascens, que difere pelas nervuras visivelmente mais próximas à margem da lâmina, lacínias externas do cálice e estames maiores, e pelas anteras amarelas. Coletada com flores entre novembro e janeiro, com frutos em dezembro, janeiro e abril.

15. Leandra foveolata (DC.) Cogn. in Mart. \& Eichler, Fl. bras. 14(4): 100. 1886. Sect. Niangae.

Fig. 2n

Subarbustos 0,5 m alt. Ramos jovens bisulcados, densamente furfuráceo-estrelado (nas inflorescências) e moderadamente hirsuto, 
tricomas simples 3,2-5,4 mm compr., com base levemente alargada, eretos. Folhas com pecíolos 2-4,3 cm compr.; lâmina 11,5-15,5× 4,5-7,5 cm, cartácea, oval, ápice agudo a acuminado, margem denticulada, base cordada a obtusa, nervuras $5+2$ basais a curtamente suprabasais; faces adaxial e abaxial moderada a densamente estrigosa, tricomas simples 1,5$3 \mathrm{~mm}$ compr., base levemente alargada, levemente adpressos, e moderadamente furfuráceo-estrelada, sendo a face adaxial bulada e abaxial foveolada. Panículas 9-12,5 cm compr.; brácteas $2,8-4,8 \mathrm{~mm}$ compr., bractéolas 1-1,2 mm compr. Flores 5-meras; hipanto 4-5,5 × 2,7-3,2 mm; cálice com tubo $0,4-0,5 \mathrm{~mm}$ compr., lacínias internas $0,6-0,8$ mm compr., triangulares, lacínias externas 1,6$1,8 \mathrm{~mm}$ compr., lineares; pétalas $3,8-4,3 \mathrm{~mm}$ compr.; estames 10, conectivo inapendiculado, antera 3-3,7 mm compr., vinosa; ovário 2-2,5 $\mathrm{mm}$ compr., 3-locular, ápice com tricomas simples. Frutos não vistos.

Material selecionado: Ponta Grossa, 5.XI.1966, fl., G. Hatschbach 14654 (RB, MBM, UPCB).

Material adicional: BRASIL, RIO DE JANEIRO: Terezópolis, 29.01.1888, fr., Glaziou 16840 (R).

Distribuição: Minas Gerais, Espírito Santo, Rio de Janeiro, São Paulo e Paraná. No Paraná ocorre no Segundo Planalto, em CA.

Leandra foveolata pode ser reconhecida pelas folhas ovais, com base cordada ou obtusa, nervuras geralmente basais, face adaxial bulada e a face abaxial foveolada. Sua distinção em relação a $L$. aurea não é muito clara, mas pode ser feita através do indumento dos ramos (hirsuto) e da face abaxial das folhas (estrigoso, nunca viloso), ambos com tricomas maiores (1,5-3 mm compr.). Coletada com flores entre maio e novembro, e frutos em janeiro e junho.

16. Leandra glabrata Cogn. in Mart. \& Eichler Fl. bras. 14(4): 172. 1886. Sect. Chaetodon.

Fig. 1d

Arbustos 1-1,5 m alt. Ramos jovens levemente achatados, glabros. Folhas com pecíolos 1-3,5 cm compr.; lâmina 4-13×1,3-4,5 cm, cartácea, lanceolada a estreitamente elíptica, ápice acuminado, margem denticulada, base obtusa, 5 nervuras basais a curtamente suprabasais; face adaxial glabra, às vezes com projeções glandulares sésseis esparsas sobre nervura central, face abaxial esparsamente furfuráceo-estrelada. Panículas glomeruliformes, 7,5-16,5 cm compr.; brácteas 1-7 mm compr., bractéolas $0,7-1 \mathrm{~mm}$ compr. Flores 5-meras, sésseis; hipanto 2,8-4,5 mm compr.; cálice com tubo $0,3-0,5 \mathrm{~mm}$ compr., lacínias internas $0,4-$ $0,8 \mathrm{~mm}$ compr., curtamente triangulares ou ovais, lacínias externas 1,2-1,7 mm compr., triangulares; pétalas 2,2-3 mm compr.; estames 10 , conectivo inapendiculado, antera $1,7-2,5 \mathrm{~mm}$ compr.; ovário 3,5-4 mm compr., 3-locular, glabro. Frutos 3,7-4,7 $\times 3-3,3 \mathrm{~mm}$, sementes $0,8-1 \times 0,5-0,7 \mathrm{~mm}$.

Material selecionado: Adrianópolis, XI.2004, fl., $L$. Abe 4224 (MBM). Tunas do Paraná, X.2005, bot. e fl., J. Silva 742 (UPCB).

Material adicional: BRASIL. ESPÍRITO SANTO: Domingos Martins, XI.1986, fl., G. Hatschbach 50775 (MBM). Marechal Floriano, XI.1993, fl., G. Hatschbach 60102 (MBM). MINAS GERAIS: Santa Bárbara, XII.1978, fl. e fr., Stubblebine 9636 (MBM). Distribuição: Minas Gerais, Espírito Santo e Paraná, onde ocorre no Primeiro Planalto (Vale do Ribeira), em FOM e transição FD-FOM.

Esta espécie pode ser reconhecida pelas folhas lanceoladas a estreitamente elípticas, cartáceas, essencialmente glabras, e pelas panículas glomeruliformes. Coletada com flores entre outubro e dezembro, com frutos entre dezembro e fevereiro.

17. Leandra gracilis Cogn. in Mart. \& Eichler Fl. bras. 14(4): 163. 1886. Sect. Oxymeris. Fig. $2 q$

Arbustos, 1,0-1,5 m alt. Ramos jovens levemente achatados, densamente furfuráceoestrelados. Folhas com pecíolos $0,3-1,5 \mathrm{~cm}$ compr:; lâmina 4,5-15×1,7-5,5 cm, membranácea, elíptica, ápice acuminado, margem denticulada ciliada, base longamente atenuada, raramente cuneada, nervuras $3+2$ suprabasais; face adaxial moderadamente furfuráceo-estrelada, face abaxial moderadamente furfurácea, raro esparsamente pubescente, tricomas simples $0,6-0,8 \mathrm{~mm}$ compr, base não alargada, sinuosos. Panículas 3-9 cm compr.; brácteas 0,6-1,8 
mm compr., bractéolas 0,4-1,8 mm compr. Flores 5-meras; hipanto 1,8-2,5 mm compr; cálice com tubo 0,2-0,3 mm compr., lacínias internas 0,4-0,9 mm compr., triangulares a oblongas, lacínias externas 0,6-1,0 mm compr., cilíndricas a lineares; pétalas 1,5-2,5 mm compr; estames 10, conectivo inapendiculado, antera 1-1,4 mm compr., alva; ovário 1,5-2 mm, 3locular, ápice glabro. Frutos 4-5 × 3-4 mm 250-300 sementes, 0,6-0,9 × 0,4-0,6 mm. Material selecionado: Adrianópolis, 12.XII.2006, fl., E. Camargo 62 (UPCB). Guaratuba, 30.XI.1958, fl. e fr., G Hatschbach 5238 (MBM, UPCB). Morretes, 29.XI.1966, fl. e fr., G. Hatschbach 15303 (MBM, UPCB). Piraquara, 22.X.2005, fl., R. Goldenberg 791 (MBM, UPCB). São José dos Pinhais, I.2004, fr., $A$. Dunaiski 2228 (MBM). Tunas do Paraná, 17.X.2005, fl., R. Goldenberg 746 (MBM, UPCB).

Distribuição: Rio de Janeiro, São Paulo, Paraná e Santa Catarina. No Paraná ocorre no Litoral, Serra do Mar e Primeiro Planalto, em FD montana, submontana e terras baixas, transição FD-FOM e FOM.

Esta espécie pode ser caracterizada pelas folhas elípticas, membranáceas, com a base longamente atenuada, e ramos e folhas com indumento furfuráceo-estrelado, às vezes também pubescentes. Vários espécimes examinados estavam determinados como $L$. sabiaensis Brade, espécie citada para Santa Catarina (Wurdack 1962). Como não foi possível distinguir as duas espécies, neste trabalho optou-se por nomear todo o material como L. gracilis, cujo nome é mais antigo. Ver comentários em $L$. acutiflora. Com flores entre outubro e dezembro, com frutos entre novembro e janeiro.

18. Leandra hatschbachii Brade, Arq. Jard. Bot. Rio de Janeiro, 14: 246. 1956. Sect. Chaetodon.

Fig. $2 \mathrm{~g}$

Arbustos 1,5-2,5 m alt. Ramos jovens cilíndricos a levemente achatados, moderado a densamente furfuráceo-estrelados. Folhas com pecíolos 1-2 cm compr.; lâmina 6,5-13,5 $\times 2-4,8 \mathrm{~cm}$, membranácea, oblongo-lanceolada, ápice acuminado, margem denticulada, base obtusa, nervuras $3+2$ suprabasais; face adaxial bulada, esparsamente estrigosa, tricomas simples 0,5 mm compr., base levemente alargada, eretos, e moderadamente estrelado-furfurácea, face abaxial moderadamente furfuráceo-estrelada. Panículas 3,5-9,5 cm compr.; brácteas 1,5-2 mm compr., bractéolas 0,7-0,8 mm compr. Flores 5-meras; hipanto 3-4 mm compr.; cálice com tubo 0,2-0,3 mm compr., lacínias internas 0,50,7 mm compr., triangulares, lacínias externas 1-1,2 mm compr., cilíndricas a lineares; pétalas 2,5-3,3 mm; estames 10, conectivoinapendiculado, antera 1,7-2 mm compr; ovário 1,5-2,8 mm, 4-locular, ápice com tricomas simples. Frutos 6-7×3-4 mm, 150-300 sementes, $1 \times 0,5 \mathrm{~mm}$. Material selecionado: Campina Grande do Sul, 24.X.2005, bot. e fl., R. Goldenberg 796 (MBM, UPCB). Piraquara, XII.1995, fl., J. Cordeiro 1286 (MBM).

Distribuição: Endêmica do Paraná, na Serra do Mar, em FD altomontana e montana.

Esta espécie pode ser caracterizada pelas folhas oblongo-lanceoladas, com 3+2 nervuras suprabasais e ápice acuminado. A face adaxial é bulada, com indumento mesclado (estrigoso e furfuráceo-estrelado). Encontrada em áera de FOD altomontana e montana. Com flores entre outubro e dezembro, com frutos em julho.

19. Leandra humilis (Cogn.) Wurdack, Sellowia 14: 202. 1962. Sect. Chaetodon.

Fig. 1b

Subarbustos a arbustos 0,4-1,5 m alt. Ramos jovens achatados, esparsamente estrigosos, tricomas simples 1-1,5 mm compr., com base levemente alargada, levemente adpressos. Folhas com pecíolos $1-2,7 \mathrm{~cm}$ compr.; lâmina 3,8-7 ×2,5-5,2 cm, cartácea, oval, ápice agudo, margem lisa a levemente denticulada, base cordada, 5 nervuras basais; faces adaxial e abaxial esparsamente estrigosas, tricomas simples 0,5-1,2 mm compr., base levemente alargada, levemente adpressos. Panículas 0,5-2,8 cm compr.; brácteas e bractéolas involucrais, 1,7-3 mm compr. Flores 5-meras; hipanto 2,3-3,5 mm compr.; cálice com tubo 0,2-0,3 mm compr., lacínias internas 0,4-1,2 mm compr., curtamente triangulares a ovais, lacínias externas 1-2,2 mm compr., 
estreitamente triangulares; pétalas 3,2-3,7 mm compr.; estames 10, conectivo apendiculado, antera 2,4-2,7 mm compr., alva; ovário 1,32,7 mm compr., 3-locular, glabro. Frutos 4-4,5 $\times 3,5-4 \mathrm{~mm}, 250-300$ sementes, $0,6-0,8 \times$ $0,4-0,6 \mathrm{~mm}$.

Material selecionado: Guaratuba, II.2000, fr., $J$. Cordeiro 3261 (MBM). Campina Grande do Sul, 25.X.2005, bot. e fl., R. Goldenberg 799 (UPCB).

Material adicional: BRASIL. SANTA CATARINA: Rancho Queimado, IX.1986, bot., D. Falkenberg 3463 (MBM). MINAS GERAIS: São Roque de Minas, VII.1995, fr., Schiavini 2594 (MBM).

Distribuição: Minas Gerais, São Paulo, Paraná e Santa Catarina. No Paraná, ocorre na Serra do Mar, em FD altomontana e montana.

Esta espécie assemelha-se a $L$. calvescens e a $L$. pallida, mas difere pela presença de tricomas simples nas folhas, e principalmente pelas brácteas envolvendo a base do hipanto. Com flores de outubro a dezembro, e com frutos entre dezembro e fevereiro, e julho.

20. Leandra ionopogon (Mart.) Cogn. in Mart. \& Eichler, Fl. bras. 14(4): 129. 1886. Sect. Carassanae.

Fig. 2r, 3d

Arbustos 1-2,5 m alt. Ramos jovens cilíndricos, moderadamente estrigosos, tricomas simples $1,3-1,8 \mathrm{~mm}$ compr., base levemente alargada, eretos, às vezes também esparso a moderadamente furfuráceoestrelado. Folhas com pecíolos 1-7 cm compr; lâmina 5,5-15×3-8 cm, cartácea, oval a elíptica, ápice acuminado, menos frequentemente agudo, margem denticulada, base obtusa a cuneada, nervuras 5 a $5+2$ suprabasais; face adaxial moderada a densamente estrigosa, tricomas simples 1,5-2 mm compr., base levemente alargada, eretos, face abaxial esparsa a moderamente pubescente, tricomas simples $0,7-1,5 \mathrm{~mm}$ compr., base não alargada, sinuosos. Panículas 4,5-12,5 cm compr., às vezes com ramos adicionais axilares; brácteas 2,5-5 mm compr., bractéolas $0,4-0,7 \mathrm{~mm}$ compr. Flores 5-meras; hipanto 3,5-5,3 mm compr.; cálice com tubo $0,3-0,5 \mathrm{~mm}$ compr., lacínias internas 1-2 mm compr., triangulares a oblongas, lacínias externas 3,5-8 mm compr., lineares cilíndricas; pétalas 4,3-5,2 mm compr.; estames 10, conectivo inapendiculados, antera 2,3-2,6 mm compr., amarela; ovário 2,5-3,5 mm compr., 3-locular, ápice com tricomas simples. Frutos 5-6 × 4-5 mm, 180-300 sementes, $1 \times 0,5-0,7 \mathrm{~mm}$.

Material selecionado: Antonina, 15.I.1976, fl., G. Hatschbach 37947 (MBM). Guaratuba, 12.XII.1993, fl., J. Silva 1289(MBM). Morretes, 23.I.1969, fl., G. Hatschbach 20884 (MBM). Paranaguá, 2.VII.2000, fr., C. Kozera 1449 (UPCB). Pontal do Paraná, 9.II.2002, fr., J. Carneiro 1290(MBM).

Distribuição: Bahia, Espírito Santo, Rio de Janeiro, São Paulo, Paraná e Santa Catarina. No Paraná, ocorre no Litoral e Serra do Mar, em de FD terras baixas.

Leandra ionopogon pode ser reconhecida principalmente pelas longas lacínias externas no cálice. A presença de inflorescências axilares, juntamente com as inflorescências terminais, foi verificada em dois espécimes analisados. Em duas coletas também foi verificada sua ocorrência como epífita. Coletada com flores entre dezembro e fevereiro, com frutos em fevereiro e julho.

21. Leandra itatiaiae (Wawra) Cogn. in Mart. \& Eichler, Fl. bras. 14(4): 173-174. 1886. Sect. Chaetodon.

Fig. 1p

Subarbustos 0,3-0,7 m alt. Ramos cilíndricos, esparsamente furfuráceoestrelados e moderadamente pubescentes, tricomas simples $0,8-1,3 \mathrm{~mm}$ compr., com base não alargada, sinuosos. Folhas com pecíolos 0,3-0,5 cm compr., lâmina $2-4 \times 1-2 \mathrm{~cm}$, cartácea, elíptica a lanceolada, ápice agudo, margem lisa, base cuneada a obtusa, $3+2$ nervuras basais; face adaxial esparsamente estrigosa, tricomas simples $0,2-0,8 \mathrm{~mm}$ compr., base levemente alargada, levemente adpressos, dispostos em faixas entre as nervuras principais, face abaxial esparsamente pubescente, tricomas simples $0,4-1,2 \mathrm{~mm}$ compr., base não alargada, sinuosos. Panículas 1,4-2,7 cm compr.; brácteas $0,8-1,6 \mathrm{~mm}$, bractéolas $0,6-0,8 \mathrm{~mm}$ compr. Flores 5-meras; hipanto 2,3-3,2 mm compr.; cálice com tubo 0,3-0,4 mm compr., lacínias internas 0,4-0,7 
mm compr., curtamente triangulares, lacínias externas 1,3-2,5 mm compr., lanceoladas; pétalas 2,7-3,8 mm compr.; estames 10 , conectivo inapendiculado, antera $2-3 \mathrm{~mm}$ compr., alva; ovário 2-2,3 mm compr., 3locular, glabro. Frutos não vistos.

Material selecionado: Campina Grande do Sul, 25.X.2005, fl., R. Goldenberg 801 (UPCB). Piraquara, XI.2003, fl., J. Cordeiro 2108 (MBM).

Distribuição: Rio de Janeiro, São Paulo, Paraná e Santa Catarina. No Paraná, ocorre na Serra do Mar, em refúgios altomontanos.

Esta espécie pode ser reconhecida pelas folhas pequenas (2-4 cm compr.) elípticas a lanceoladas, e pelos tricomas simples esparsos, normalmente dispostos em linhas na face adaxial. Coletada com flores em outubro e novembro.

22. Leandra kleinii Brade, Sellowia 12: 140. 1960. Sect. Chaetodon. Fig. 1k

Subarbustos a arbustos 0,7-1,2 m alt. Ramos jovens achatados, moderadamente furfuráceo-estrelados e moderada a densamente pubescentes, tricomas simples $0,5-0,6 \mathrm{~cm}$ compr., com base não alargada, sinuosos. Folhas com pecíolos 1,3-2 cm compr.; lâmina 5-10,5 ×2$3,4 \mathrm{~cm}$, membranácea, oval a elíptica, ápice acuminado, margem lisa a levemente denticulada, base obtusa, 3+2 nervuras suprabasais; face adaxial bulada, nervuras nitidamente demarcadas, esparsamente estrigosa, tricomas simples 0,2$0,4 \mathrm{~mm}$ compr., base levemente alargada, eretos, e moderadamente furfuráceo-estrelado, face abaxial densamente pubescente, tricomas simples 0,3-1 mm compr., base não alargada, sinuosos e esparsamente furfuráceo-estrelada. Panículas 4,5-5,7 cm compr.; brácteas 1-1,7 mm compr., bractéolas 0,7-1 mm compr. Flores 5meras; hipanto 2,5-3,3 mm compr; cálice com tubo 0,3-0,4 mm compr., lacínias internas 0,6$0,8 \mathrm{~mm}$ compr., curtamente triangulares, lacínias externas 1,6-2,7 mm compr., lineares; pétalas 3,2-3,5 mm compr.; estames 10 , conectivo inapendiculado, antera $2-2,5 \mathrm{~mm}$ compr.; ovário 2-2,3 mm compr., 3-locular, ápice com tricomas simples. Frutos não vistos. Material selecionado: Tijucas do Sul, XI.1961, fl., G. Hatschbach 8556 (MBM).
Material adicional: BRASIL. SANTACATARINA: Lajes, XII.1962, fl., Klein 3172 (MBM). Urubici, XII.2000, fl., Barbosa 71765 (MBM).

Distribuição: Paraná e Santa Catarina. No Paraná, ocorre no Primeiro Planalto, em FOM.

Esta espécie pode ser reconhecida principalmente pelas folhas com a face adaxial bulada, com nervuras nitidamente demarcadas. Os ramos são densamente recobertos por indumento pubescente e furfuráceo-estrelado. Pode ser confundida com L. laxa, que difere pelo hipanto menor (até 2,5 mm compr.), e pelas lacínias externas do cálice menores que as internas. Coletada com flores em novembro e dezembro.

23. Leandra laevigata (Triana) Cogn. in Mart. \& Eichler, Fl. bras. 14(4): 177. 1886. Sect. Chaetodon. Fig. 1f, 3a

Arbustos a arvoretas 1-3,5 m alt. Ramos jovens achatados, glabros. Folhas com pecíolos 0,8-5 cm compr; lâmina 4,5-15 × 1,5-6 cm, membranácea, elíptica a oval, ápice acuminado, margem lisa a levemente denticulada, base cuneada a obtusa, 3+2 ou 5 nervuras suprabasais; faces adaxial e abaxial glabras, menos frequentemente com projeções glandulares sésseis. Panículas 2,3-11,5 cm compr.; brácteas 0,8-2,5 mm compr., bractéolas 0,5-1,2 mm compr. Flores 5-meras; hipanto 2,2-3,6 mm compr.; cálice com tubo 0,3-0,5 mm compr., ' lacínias internas 0,3-0,8 mm compr., curtamente triangulares, lacínias externas 1,3-3 mm compr., lineares; pétalas 3-4,5 mm compr.; estames 10, conectivo com apêndice curto dorsal, antera 1,7-2,2 mm compr., alva; ovário 1,7-2,5 mm compr., 5locular, glabro. Frutos 3,3-5 × 2,8-4,8 mm, 200-550 sementes, 0,5-0,6 $\times 0,2-0,3 \mathrm{~mm}$.

Material selecionado: Adrianópolis, XI.1999, fr., $L$. Abe 402 (MBM). Balsa Nova, X.1980, fl., G. Hatschbach 43234 (MBM). Bituruna, XI.2003, fl., D. Liebsch 689 (UPCB). Campina Grande do Sul, XI.1968, bot. e fl., G. Hatschbach 20271 (MBM, UPCB). Curitiba, X.1974, bot., N. Imaguire 3482 (MBM). Guaraqueçaba, IV.2002, fr., M. Scheer 385 (MBM). Guaratuba, XI.1996, fl., J. Saldanha 1791 (MBM). Lapa, s.d., bot., R. Canepagnolo 378 (MBM). Morretes, VI.2003, fl., A. Cervi 8554 
(UPCB). Palmeira, X.1982, fl., G Hatschbach 45722 (MBM). Piraquara, XI.2004, fl., M. Reginato 107 (UPCB). Ponta Grossa, II.2005, fr., M. Reginato 216 (UPCB). Quatro Barras, XI.1988, fl., G Hatschbach 52532 (MBM). São José dos Pinhais, XI.1978, fl., G. Hatschbach 41811 (MBM). Tijucas do Sul, X.1974, fl., G. Hatschbach 40400 (MBM). Tunas do Paraná, X.2005, fl., J. Silva 733 (UPCB).

Distribuição: Minas Gerais, Rio de Janeiro, São Paulo, Paraná, Santa Catarina e Rio Grande do Sul. No Paraná, ocorre desde o Litoral até a divisa do Segundo e Terceiro Planaltos, em FD até transição FOM-FE.

Esta espécie apresenta ramos e folhas essencialmente glabros. Assemelha-se a $L$. pilonensis, da qual difere pelas nervuras $3+2$ suprabasais, folhas e ramos jovens essencialmente glabros, além do ovário 5-locular. Ver comentários em L. refracta. Coletada com flores em junho, e entre setembro e janeiro, com frutos entre novembro e abril.

24. Leandra laxa Cogn. in A. DC. \& C. DC., Monogr. Phan. 7: 642. 1891. Sect. Carassanae. Fig. 1i

Arbustos, 1-2 m alt. Ramos jovens cilíndricos, densamente furfuráceo-estrelados e moderadamente estrigosos, tricomas simples 0,7-1 mm compr., com base levemente alargada, levemente adpressos. Folhas com pecíolos 0,6-2,2 cm compr., lâmina 5-11,5 $\times$ 1,8-4,2 cm, membranácea, lanceolada ou ovallanceolada, ápice acuminado, margem lisa a levemente denticulada, base obtusa a cuneada, nervuras 5 suprabasais; face adaxial moderadamente estrigosa, tricomas simples $0,3-0,5 \mathrm{~mm}$ compr., base levemente alargada, levemente adpressos, mesclado com projeções glandulares sésseis, face abaxial moderada a densamente pubescente, tricomas simples 0,6-0,8 mm compr., base não alargada, e esparsamente furfurácea estrelada, nervuras areoladas nitidamente demarcadas, $0,3-0,5 \mathrm{~mm}$ diâmetro. Panículas 4,5-8,5 cm compr.; brácteas 3-6,3 mm compr., bractéolas 1,8-2,5 mm compr. Flores 4-5-meras; hipanto 2-2,5 mm compr; cálice com tubo $0,2 \mathrm{~mm}$ compr., lacínias internas 0,5-0,8 mm compr., oblongas, lacínias externas 0,3-0,5 mm compr., cilíndricas; pétalas 1,8-2,2 mm compr.; estames 8-10, conectivo inapendiculado, antera 1,4-1,7 mm compr., rósea; ovário 1,3-1,5 mm compr., 3locular, ápice glabro. Frutos 4,5-5 × 3,2-3,7 $\mathrm{mm}$, sementes $0,6-0,7 \times 0,2-0,3 \mathrm{~mm}$.

Material selecionado: Piraquara, 1.IV.2006, fr., E. Camargo 5 (UPCB). Quatro Barras, 16.XII.1996, fl., G. Gatti 132 (UPCB). União da Vitória, 15.XI.1998, bot., G. Hatschbach 68870 (UPCB).

Material adicional: BRASIL, SANTA CATARINA: Blumenau, 3.II.2001, fr., M. Sobral, s.n. (UPCB 45047).

Distribuição: Minas Gerais, Rio de Janeiro, São Paulo, Paraná, Santa Catarina e Rio Grande do Sul. No Paraná, ocorre no Primeiro e Terceiro Planaltos, em FOM e transição FOM-FE.

Leandra laxa pode ser reconhecida pelas folhas lanceoladas, com 5 nervuras suprabasais, face adaxial com tricomas curtos e face abaxial nitidamente reticulada/areolada, com aréolas menores que $0,5 \mathrm{~mm}$. Ver comentários em $L$. kleinii. Coletada com flores entre novembro e fevereiro, com frutos entre fevereiro e abril.

25. Leandra longisetosa Cogn. in Mart. \& Eichler, Fl. bras. 14(4): 181. 1886. Sect. Chaetodon.

Fig. 1q

Arbustos 1,5-2 m alt. Ramos jovens achatados, esparso a moderadamente estrigosos, tricomas simples 0,7-2 mm compr., com base levemente alargada, eretos, mesclado com projeções glandulares sésseis. Folhas com pecíolos alados, 0,4-2,5 cm compr.; lâmina 8,5$30 \times 3-11 \mathrm{~cm}$, membranácea, largamente elíptica, ápice acuminado, margem denticulada, base atenuada, 5 ou $5+2$ nervuras suprabasais; face adaxial densamente estrigosa, tricomas simples 0,2-1 mm compr., base levemente alargada, eretos, mesclado com projeções glandulares sésseis, face abaxial densamente pubescente, tricomas simples $0,3-1,3 \mathrm{~mm}$ compr., base não alargada, sinuosos, e esparsamente furfuráceo-estrelado sobre nervura central. Panículas 2-10 cm compr.; brácteas 0,8-2,5 mm compr., bractéolas 0,6$1 \mathrm{~mm}$ compr. Flores 5-meras; hipanto 3-4,5 $\times$ 2-3 mm; cálice com tubo 0,2-0,5 mm compr., 
lacínias internas $0,4-0,8 \mathrm{~mm}$ compr., curtamente triangulares, lacínias externas 3$5 \mathrm{~mm}$ compr., estreitamente triangulares; pétalas 3,7-4,7 mm compr.; estames 10, conectivo inapendiculado, antera 2,2-3 mm compr., alva; ovário 2,2-2,6 mm compr., 3locular, glabro. Frutos 4-4,8 × 3-4,5 mm, 50150 sementes, $0,6-0,8 \times 0,2-0,4 \mathrm{~mm}$.

Material selecionado: Campina Grande do Sul, XI.1968, fl., G. Hatschbach 20331 (MBM). Morretes, XI.1980, fl., G. Hatschbach 43271 (MBM). Piraquara, X.2005, fl., R. Goldenberg 790 (UPCB).

Distribuição: Rio de Janeiro, São Paulo e Paraná. Neste estado ocorre entre a Serra do Mar e o Primeiro Planalto, em transição FD-FOM.

Esta espécie pode ser reconhecida principalmente pelas folhas largamente elípticas, com base longamente atenuada, às vezes com pecíolo alado. Alguns materiais examinados estavam determinados como $L$. multiplinervis. Cogniaux (1886-1888) cita que L. longisetosa possui ramos estrigosos, enquanto L. multiplinervis teria ramos glabros ou pubérulos. Coletada com flores entre julho e novembro, com frutos em janeiro e fevereiro.

26. Leandra microphylla Cogn. in A. DC. \& C. DC., Monogr. Phan. 7: 655. 1891. Sect. Carassanae.

Fig. 1s

Subarbustos, 0,2-0,6 m alt. Ramos jovens cilíndricos, densamente estrigoso-dendríticos, tricomas simples 0,3-1 mm compr., com base levemente alagada, eretos, mesclados com tricomas dendríticos 0,4-0,8 mm compr., com eixo alargado. Folhas com pecíolos $0,1-0,4 \mathrm{~cm}$ compr., lâmina 1-3×0,5-1,6 cm, membranácea, oval ou elíptica, ápice agudo, margem lisa a levemente denticulada, base obtusa a cordada, nervuras $3+2$ basais; faces adaxial e abaxial moderado a densamente estrigoso-dendrítico, tricomas simples $0,4-0,8 \mathrm{~mm}$ compr., base levemente alargada, eretos, mesclados com tricomas dendríticos, 0,2-0,8 mm compr., eixo alargado. Panículas 0,7-1,5 cm compr.; brácteas 0,5-2 mm compr., bractéolas 0,5-1,5 mm compr. Flores 4-5-meras; hipanto 2-3 mm compr.; cálice com tubo 0,3-0,4 mm compr., lacínias internas 0,4-0,8 mm compr., triangulares, lacínias externas 1,6-2,8 mm compr., lineares; pétalas 2-3 mm compr.; estames 8-10, conectivo inapendiculado, antera 1,6-2 mm compr., alva; ovário 1,5-2 mm compr., 3-locular, ápice com tricomas dendríticos. Frutos 3,5×2,5 mm, 130 sementes $0,6 \times 0,4 \mathrm{~mm}$.

Material selecionado: Campo Largo, 6.XI.2001, fl., R. Goldenberg 538 (UPCB). Ponta Grossa, 21.X.1989, bot., A. Cervi 2882 (UPCB). Tibagi, 6.XII.2007, fl., E. Camargo 158(UPCB).

Distribuição: Endêmica do Paraná, onde ocorre no Segundo Planalto, em CA. Normalmente são encontradas em fendas de rochas e em afloramentos de arenito.

Leandra microphylla pode ser reconhecida pelas folhas diminutas, com até 3 $\mathrm{cm}$ de comprimento. As folhas possuem nervuras basais, com tricomas dendríticos em ambas as faces, assim como nos ramos. A maior parte do material examinado nos herbários estava identificada como L. dusenii Cogn. Cogniaux (1891) e Wurdack (1970) distinguiram ambas as espécies pela presença de indumento no torus e estilete, pelo comprimento dos dentes externos do cálice e forma das anteras. Foram observados estádios intermediários nos espécimes analisados, que confirmam a suspeita de Wurdack (1970) de que provavelmente trata-se de apenas uma espécie. O nome aqui adotado, L. microphylla, é o mais antigo. Coletada com flores entre setembro e janeiro, com frutos em fevereiro.

27. Leandra neglecta Brade, Sellowia 8:375. 1957. Sect. Oxymeris.

Fig. 2v, 3j

Subarbustos a arbustos, 0,5-0,8 m alt. Ramos jovens cilíndricos, glabros a moderadamente furfuráceos. Folhas com pecíolos 0,3-1 cm compr.; lâmina 3,5-7 × 1$2 \mathrm{~cm}$, coriácea, elíptica a oblongo-elíptica, ápice agudo a acuminado, margem revoluta, base obtusa a cuneada, nervuras 3 basais; face adaxial glabra, com as nervuras principais e secundárias não marcadas ou visíveis, face abaxial glabra a esparsamente furfurácea. Panículas 4-10 cm compr., quase laterais; brácteas 0,7-1,5 mm compr., bractéolas 0,5- 
0,8 mm compr. Flores 5-meras; hipanto 2,5$3,5 \mathrm{~mm}$; cálice com tubo $0,2-0,3 \mathrm{~mm}$ compr., lacínias internas $0,5-0,8 \mathrm{~mm}$ compr., triangulares ou oblongas, lacínias externas $0,5-0,8 \mathrm{~mm}$ compr., cilíndricas; pétalas com tricomas glandulares, 2,3-3 mm compr; estames 10 , conectivo inapendiculado, antera $2-2,2 \mathrm{~mm}$ compr., alva; ovário 1,8-2,8 mm compr., 3locular, ápice glabro. Frutos não vistos.

Material selecionado: Guaratuba, VIII.2002, fl., A. Cervi 8314 (UPCB).

Distribuição: Paraná e Santa Catarina. No Paraná ocorre na Serra do Mar, em FOD altomontana.

Esta espécie pode ser caracterizada pelas folhas coriáceas, com 3 nervuras basais, observadas apenas pela face abaxial. As flores são alvas, com tricomas glandulares nas pétalas. Ao contrário do observado em $L$. quinquedentata, a face abaxial não possui tricomas na base das nervuras formando domácias. É possível que L. neglecta seja sinônimo de L. quinquedentata var. depauperata Cogn. (Wurdack (1962). Coletada com flores entre agosto e novembro.

28. Leandra pallida Cogn. in Mart. \& Eichler, Fl. bras. 14(4): 167. 1886. Sect. Chaetodon. Fig. 1a

Subarbustos $0,2-0,5 \mathrm{~m}$ alt. Ramos jovens achatados a cilíndricos, densamente furfuráceoestrelados e esparsamente pubescentes, tricomas simples $0,4-0,8 \mathrm{~mm}$ compr., com base não alargada, sinuosos. Folhas com pecíolos 0,6-2,0 cm compr; lâmina 1,7-4,5 × 1-2,8 cm, membranácea, oval, ápice agudo, margem lisa, base cordada a obtusa, $3+2$ nervuras basais; faces adaxial e abaxial esparsamente furfuráceoestrelada, mesclado com projeções glandulares sésseis. Panículas 2-6,3 cm compr.; brácteas 1-2 mm compr., bractéolas $0,8-1,3 \mathrm{~mm}$ compr. Flores 5-meras; hipanto 1,5-2,8 mm compr.; cálice com tubo $0,2-0,3 \mathrm{~mm}$ compr., lacínias internas $0,3-0,5 \mathrm{~mm}$ compr., triangulares a ovais, lacínias externas $0,7-1 \mathrm{~mm}$ compr., triangulares; pétalas $2-3,2 \mathrm{~mm}$ compr.; estames 10 , conectivo inapendiculado, antera 1,4-1,8 mm compr., alva; ovário 1,4-1,6 mm compr., 3-locular, ápice com projeções glandulares sésseis. Frutos não vistos.
Material selecionado: Campina Grande do Sul, X.2005, fl., R. Goldenberg 794 (UPCB).

Material adicional: BRASIL. SANTACATARINA: Campo Alegre, fl., XI.1992, J. Cordeiro 912(MBM). RIO GRANDE DO SUL: Cambará do Sul, XI.1994, fl., G Hatschbach 61313 (MBM). RIODE JANEIRO: Macieiras, XI.1980, fl., Occhioni 9219(MBM).

Distribuição: Rio de Janeiro, São Paulo, Paraná e Santa Catarina. Neste estado, ocorre na Serra do Mar, em FD altomontana.

Esta espécie pode ser reconhecida pelas folhas ovais, 1,7-4,5 mm compr., com base cordada, faces adaxial e abaxial com indumento furfuráceo-estrelado mesclado com projeções glandulares sésseis, assim como no ápice do ovário. Ver comentários em L. calvescens. Coletada com flores entre outubro e novembro.

29. Leandra pilonensis Wurdack, Sellowia 14: 204. 1962. Sect. Chaetodon. Fig. $2 \mathrm{~h}$

Arbustos a arvoretas 1,5-3 m alt. Ramos jovens achatados, moderadamente furfuráceoestrelados, posteriormente glabrescentes. Folhas com pecíolos 0,5-2 cm compr.; lâmina $8,2-12 \times 2-3,5 \mathrm{~cm}$, membranácea, oblongolanceolada, ápice agudo, margem denticulada, base cuneada, 3 nervuras curtamente suprabasais; faces adaxial e abaxial glabras. Panículas 4-6 cm compr.; brácteas 2-6,7 mm compr., bractéolas 1,4-2,3 mm compr. Flores 5-6-meras; hipanto 3-4,5 mm compr.; cálice com tubo $0,5-0,6 \mathrm{~mm}$ compr., lacínias internas 0,4-1 mm compr., largamente triangulares, lacínias externas 2-2,5 mm compr., estreitamente triangulares; pétalas 4-4,5 mm compr., triangulares, glabras; estames 10-12, conectivo e com apêndice curto dorsal, antera 2,2-2,4 mm compr.; ovário 2,8-3 mm, 3-locular, glabro. Frutos 4,6-5,5 × 3,6-4,2 mm, 90-120 sementes, $0,8-1 \times 0,5-0,6 \mathrm{~mm}$.

Material selecionado: Morretes, I.2000, fl. e fr., $R$. Goldenberg 690 (UPCB).

Material adicional: BRASIL. SANTA CATARINA: Anitápolis, IV.1992, fr., D. Falkenberg 5728 (MBM). Antônio Carlos, VI.1992, fr., Zanin 5802 (MBM). Palhoça, XII.1971, fl., Bresolin 431 (MBM). Paulo Lopes, XII.1973, fl., Bresolin 1054 (MBM). SÃO PAULO: São MiguelArcanjo, I.1995, fr., Ivanauskas 1167 (UPCB). 
Distribuição: São Paulo, Paraná e Santa Catarina. No Paraná, ocorre na Serra do Mar, em FD altomontana.

Esta espécie pode ser reconhecida pelas folhas oblongo-lanceoladas, glabras, normalmente com 3 nervuras curtamente suprabasais, próximas à margem da lâmina. Wurdack (1962) mencionou a afinidade desta espécie a $L$. brackenridgei (A. Gray) Cogn., que difere pelos ramos e hipanto pubérulos. Ver comentários em $L$. laevigata. Coletada com flores entre outubro e janeiro, com frutos entre janeiro e junho.

30. Leandra polystachya (Naudin) Cogn. in Mart. \& Eichler, Fl. bras. 14(4): 132. 1886. Sect. Carassanae. Fig. $2 b, 3 b$

Subarbustos a arbustos, 0,5-1,5 m alt. Ramos jovens cilíndricos, glabros ou esparsamente furfuráceo-estrelados e moderadamente estrigosos a pubescentes, tricomas simples $0,6-1,2 \mathrm{~mm}$ compr., com base não alargada a levemente alargada, levemente adpressos a sinuosos. Folhas com pecíolos $0,1-$ 0,5 cm compr.; lâmina 4-11,5 × 2,5-6 cm, cartácea, elíptica a oval, ápice agudo, margem lisa a levemente denticulada, base levemente cordada, às vezes obtusa, nervuras 5 a $5+2$ basais; face adaxial glabra ou esparsa a moderadamente estrigosa, tricomas simples 0,5-1 mm compr., base levemente alargada, adpressos a eretos, face abaxial glabra ou esparsa a moderadamente pubescente, tricomas simples $0,4-0,6 \mathrm{~mm}$ compr., base não alargada, sinuosos, e moderadamente furfuráceoestrelada sobre as nervuras. Panículas glomeruliformes 6-19 $\mathrm{cm}$; brácteas $2-5 \mathrm{~mm}$ compr., bractéolas 1,3-2,5 mm compr. Flores 5-meras, sésseis; hipanto 3-4,5 mm compr.; cálice com tubo 0,2-0,4 mm compr., lacínias internas $0,5-0,7 \mathrm{~mm}$ compr., triangulares ou oblongas, lacínias externas 1,5-2,5 mm compr., lineares; pétalas 3,2-4 mm compr.; estames 10 , conectivo com apêndice dorsal curto, antera 2,3-3,2 mm compr., rósea; ovário 1,6-2,2 mm compr., 3-locular, ápice com tricomas simples. Frutos $5,5-8,5 \times 4,5-7,5 \mathrm{~mm}, 100-120$ sementes, $0,9-1,1 \times 0,5-0,7 \mathrm{~mm}$.
Material selecionado: Almirante Tamandaré, 27.II.1978, fl., G. Hatschbach 41165 (MBM). Araucária, 16.II.1968, fl., L. Dombrowski 2918 (MBM). Balsa Nova, 2.V.1999, fl., S. Ziller 1948 (MBM). Bocaiúva do Sul, 16.X.1949, fl., G. Hatschbach 1544 (MBM). Campo Largo, 10.IV.1979, fr., L. Dombrowski 10456 (MBM). Carambeí, 3.X.1964, fl., G. Hatschbach 11678 (MBM). Castro, 9.V.1992, fl., M. Dias s.n. (FUEL 18008). Colombo, 14.II.1975, fl., R. Kummrow 895 (MBM). Curitiba, 30.X.1973, fl., G. Hatschbach 32734 (MBM). Jaguariaíva, 2.XI.1989, fl., A. Cervi 2979 (MBM). Lapa, 5.X.1958, fl., G. Hatschbach 5053 (MBM). Palmeira, 20.X.1989, fl., V.Nicolak 59 (MBM). Ponta Grossa, 10.X.1967, fl., G. Hatschbach 17396 (MBM). Tibagi, 6.XII.2007, fl., E. Camargo 172 (UPCB).

Distribuição: Minas Gerais, São Paulo, Paraná, Santa Catarina e Rio Grande do Sul. No Paraná, ocorre no Primeiro e Segundo Planaltos, em FOM, CA e CE.

Leandra polystachya pode ser reconhecida pelas folhas ovais com nervuras basais, pecíolo curto (máximo de $0,5 \mathrm{~cm}$ compr.) e lâmina glabra ou com tricomas esparsos. Trata-se de uma espécie com variação morfológica considerável, no que se refere ao tamanho das folhas e inflorescências, e presença ou não de indumento nos ramos e folhas. Parte do material examinado nos herbários estava determinado como L. simplicicaulis (Naudin) Cogn. Cogniaux (1886-1888) caracterizou $L$. polystachya pelas folhas e ramos com tricomas, e lâmina com 9 nervuras basais, enquanto $L$. simplicicaulis teria folhas e ramos glabros, e lâmina com 7 nervuras basais. Neste trabalho optou-se por aceitar para o Estado uma única espécie, visto que foram encontrados vários espécimes com características intermediárias, e também em algumas áreas foram encontrados tanto indivíduos glabros, quanto com indumento. Coletada com flores entre em praticamente todos os meses do ano, com frutos em novembro, dezembro, abril e maio.

31. Leandra purpurascens (DC.) Cogn. in Mart. \& Eichler, Fl. bras. 14(4): 110. 1886. Sect. Carassanae.

Fig. $1 \mathrm{~h}$

Arbustos 0,8-2 m alt. Ramos jovens cilíndricos, moderadamente furfuráceo- 
estrelados e densamente vilosos a estrigosos, tricomas simples $0,6-1,5 \mathrm{~mm}$ compr., com base não alargada a levemente alargada, enovelados a eretos. Folhas com pecíolos 1-1,6 cm compr.; lâmina 7-14 × 2,2-4,3 cm, cartácea, lanceolada, ápice acuminado, margem lisa e levemente denticulada, base cuneada, nervuras 3 a $3+2$ suprabasais; face adaxial densamente estrigosa, tricomas simples $0,6-1,2 \mathrm{~mm}$ compr., base levemente alargada, levemente adpressos, face abaxial densamente vilosa, tricomas simples 0,3-0,6 mm compr., base não alargada, enovelados. Panículas 7,5-16 cm compr.; brácteas 1-3,5 mm compr., bractéolas 1-3 mm compr. Flores 5-meras; hipanto 4,3-5,5 mm compr.; cálice com tubo $0,3-0,4 \mathrm{~mm}$ compr., lacínias internas $0,8-1,3 \mathrm{~mm}$ compr., triangulares, lacínias externas $2-4,5 \mathrm{~mm}$ compr., lineares cilíndricas; pétalas 3,2-4 mm compr.; estames 10, conectivo apêndice dorsal curto, antera 3,3-3,8 mm compr., amarela; ovário 2-2,5 mm compr., 3-locular, ápice com tricomas simples. Frutos 5,5-8 $\times 4-6,5 \mathrm{~mm}$, 80-200 sementes, $1-1,2 \times 0,6-0,7 \mathrm{~mm}$.

Material selecionado: Adrianópolis, 18.X.2005, fl., R. Goldenberg 757 (UPCB). Balsa Nova, 12.XI.1980, fl., G. Hatschbach 43335 (MBM). Bituruna, 17.X.1966, fl., G. Hatschbach 14935(MBM, UPCB). Bocaiúva do Sul, 19.VIII.2004, fl., J. Silva 4085 (MBM, UPCB). Campo Largo, 13.X.1996, fl., G. Tiepolo 710 (MBM). Cascavel, 18.X.1962, fl., G. Hatschbach 9316 (MBM). Cerro Azul, 5.X.1973, fl., G Hatschbach 32656 (MBM, UPCB). Colombo, .2003, bot., R. Possette s.n. (MBM 298251). Jaguariaíva, 29.X.1999, fl., L. Von Lisingen 131 (MBM). Piraquara, 13.XI.1998, fl., A. Lacerda 102 (MBM, UPCB). Pitanga, 18.X.1973, fl., G. Hatschbach 32857 (MBM). Ponta Grossa, 19.X.2005, fl., P. Schwartsburd s.n. (UPCB 52212). Quatro Barras, 24.X.1996, fl., J. Cordeiro 1341 (MBM). Rio Branco do Sul, 9.X.1975, bot., G. Hatschbach 37313 (MBM). São José dos Pinhais, 12.VIII.1966, fl., G. Hatschbach 14600 (MBM, UPCB). Tibagi, 5.XII.2003, fr., M. Carmo 519(HUPG UPCB). Tijucas do Sul, 25.X.1971, fl., G. Hatschbach 27558 (MBM). Tunas do Paraná, 21.IV.2007, bot. e fl., E. Camargo 112 (UPCB). Ventania, 24.VIII.2004, fl., D. Estevan 467 (UPCB).

Distribuição: Piauí, Paraíba, Minas Gerais, Rio de Janeiro, São Paulo, Paraná, Santa Catarina e Rio Grande do Sul. No Paraná, ocorre nos três planaltos, em FOM, FE, CA e CE.

Leandra purpurascens apresenta folhas lanceoladas, normalmente com nervuras 3 suprabasais, sendo as nervuras laterais tênues e visivelmente bem próximas à margem da lâmina. A face abaxial possui indumento viloso. As inflorescências apresentam tricomas amarelados, e flores com estames grandes. Ver comentários em L. fallax. Coletada com flores em abril, e entre julho e novembro, com frutos entre outubro e dezembro.

32. Leandra quinquedentata (DC.) Cogn. in Mart. \& Eichler, Fl. bras. 14(4): 156. 1886. Sect. Oxymeris.

Fig. $2 \mathrm{k}$

Subarbustos a arvoretas, 0,5-2,5 $\mathrm{m}$ alt. Ramos jovens cilíndricos, glabros a esparsamente furfuráceo-estrelados. Folhas com pecíolos 0,5-2,3 cm compr.; lâmina 3,5$13,5 \times 1,2-4,2 \mathrm{~cm}$, coriácea, elípticas a oblongo-elípticas, ápice acuminado, margem revoluta, base obtusa a cuneada, nervuras 3 ou $3+2$ basais a curtamente suprabasais; face adaxial glabra, raro esparsamente furfuráceoestrelada, face abaxial furfurácea, às vezes com tricomas simples na base das nervuras primárias, formando domácias. Panículas 4,2$8,5 \mathrm{~cm}$ compr.; brácteas $0,6-2,7 \mathrm{~mm}$ compr., bractéolas 0,7-1 mm compr. Flores 5-meras; hipanto 2-3 mm compr; cálice com tubo 0,2$0,3 \mathrm{~mm}$ compr., lacínias internas $0,3-0,5 \mathrm{~mm}$ compr., largamente triangulares, lacínias externas $0,4-0,5 \mathrm{~mm}$ compr., cilíndricas; pétalas glabras ou com tricomas glandulares, 2,5-3,5 mm compr; estames 10 , conectivo inapendiculado, antera 1,2-2 mm compr., alva; ovário 1,5-2,3 mm, 3-locular, ápice glabro ou com tricomas simples. Frutos 5-12×3-5 mm, 100-200 sementes, $0,8-1 \times 0,5-0,6 \mathrm{~mm}$.

Material selecionado: Antonina, 10.III.2001, fr., $M$. Scheer 239 (UPCB). Bocaiúva do Sul, I.2004, fl., $O$. Ribas 5798 (MBM). Campina Grande do Sul, 24.X.2005, fl., R. Goldenberg 800 (MBM, UPCB). Guaraqueçaba, IV.2001, fr., M. Scheer 267 (MBM). Morretes, 24.VIII.1999, fr., D. Rosa 24 (UPCB). Piraquara, 5.XII.2004, fl., M. Reginato 129 (UPCB). São José dos Pinhais, 9.VIII.2002, fr., A. Mocochinski 59 (MBM, UPCB). 
Distribuição: Bahia, Minas Gerais, Rio de Janeiro, São Paulo, Paraná e Santa Catarina. No Paraná ocorre no litoral, Serra do Mar e Primeiro Planalto, em FD montana e submontana, e também em refúgios vegetacionais altomontanos.

Esta espécie pode ser reconhecida pelos ramos e folhas furfuráceo-estrelados, folhas coriáceas, elípticas a oblongo-elípticas, e cálice com lacínias quase indistintas do tubo. As pétalas podem possuir tricomas glandulares. Espécie altamente polimórfica, pode ser confundida com $L$. reitzii, $L$. sulfurea e $L$. neglecta. Leandra reitzii possui hipanto, lacínias do cálice e anteras maiores, e flores rodeadas por brácteas folhosas. Leandra sulfurea também possui lacínias do cálice maiores, e caducas no fruto, além de brácteas folhosas, e ramos e a face abaxial das folhas com indumento furfuráceo-estrelado. Leandra neglecta difere pelas folhas com nervuras basais e não nitidamente marcadas na face adaxial, além de glabras na face abaxial. Coletada com flores entre julho e fevereiro, com frutos de dezembro a agosto.

33. Leandra refracta Cogn. in Mart. \& Eichler, Fl. bras. 14(4): 186. 1886. Sect. Chaetodon.

Fig. $1 \mathrm{~m}$

Arbustos 0,5-2 m alt. Ramos jovens achatados, esparsa a moderadamente pubescentes, tricomas simples 0,3-1,7 mm compr., com base não alargada, sinuosos. Folhas com pecíolos 0,7-4,6 cm compr.; lâmina 4,5-11,6×1,2-4 cm, membranácea, elíptica a lanceolada, ápice acuminado, margem inteira a levemente crenada, base cuneada, 5 nervuras suprabasais; face adaxial esparsamente estrigosa, tricomas simples 0,3-1,2 mm compr., base levemente alargada, eretos, face abaxial esparsa a moderadamente pubescente, tricomas simples 0,5-1,5 mm compr., base não alargada, sinuosos. Panículas 3-10,5 cm compr.; brácteas $0,8-3,5 \mathrm{~mm}$ compr., bractéolas 0,6-1,5 mm compr. Flores 5-meras; hipanto 1,5-3 mm compr.; cálice com tubo 0,30,5 mm compr., lacínias internas 0,4-1 mm compr., curtamente triangulares, lacínias externas 1,8-4 mm compr., lanceoladas; pétalas 1,3-4,2 mm compr; estames 10 , conectivo com apêndice curto dorsal, antera 1,3-2 mm compr.alvo-amarelada; ovário 1,32,4 mm compr., 5-locular, glabro. Frutos 3,5$4,7 \times 3,8-4,5 \mathrm{~mm}, 500-800$ sementes, 0,4-0,6 $\times 0,2-0,3 \mathrm{~mm}$.

Material selecionado: Bocaiúva do Sul, X.1990, fl., G. Hatschbach 54796 (MBM). Campina Grande do Sul, X.2005, fl., J. Silva 707 (UPCB). Curitiba, X.1996, fl., V. Dittrich 238 (UPCB). Guaratuba, XI.1992, fl., G. Hatschbach 58234 (MBM, UPCB). Morretes, X.1977, fl., G. Hatschbach 40410(MBM). Piraquara, XII.1970, fl., G. Hatschbach 25712(MBM, UPCB). Quatro Barras, IV.1994, fr., J. Silva 1308 (MBM). São José dos Pinhais, XI.1999, fl., J. Cordeiro 1630 (MBM). São Mateus do Sul, X.1985, fl., R. Britez 152 (MBM). Tijucas do Sul, X.2002, bot., D. Liebsch 504 (UPCB). Tunas do Paraná, X.2005, fl., J. Silva 745 (UPCB).

Distribuição: Rio de Janeiro, São Paulo, Paraná e Santa Catarina. No Paraná, ocorre na Serra do Mar e Primeiro Planalto, em FD e transição FD-FOM.

Esta espécie pode ser reconhecida pela presença de indumento simples e ausência de indumento furfuráceo-estrelado nas partes vegetativas e reprodutivas. Assemelha-se a $L$. laevigata, que apresenta ramos glabros. Pode ser confundida com $L$. debilis, que apresenta cálice com lacínias externas menores e ovário 3-locular. Coletada com flores entre outubro e dezembro, com frutos em março e abril.

34. Leandra regnellii (Triana) Cogn. in Mart. \& Eichler, Fl. bras. 14(4): 116. 1886. Sect. Carassanae.

Fig. 2o

Arbustos a arvoretas 0,5-3 m alt. Ramos jovens cilíndricos, moderadamente furfuráceoestrelados e esparso a densamente estrigosos, tricomas simples 0,6-1,4 mm compr., com base levemente alargada, eretos. Folhas com pecíolos 1-6 cm compr.; lâmina 6,5-23 × 3,5$13 \mathrm{~cm}$, membranácea, oval a elíptica, ápice acuminado, margem levemente denticulada, base obtusa a atenuada, nervuras $5+2$ a $7+2$ suprabasais; face adaxial esparsa e densamente estrigosa, tricomas simples $0,4-0,5 \mathrm{~mm}$ compr., base levemente alargada, eretos, face abaxial esparsa a densamente pubescente, tricomas 
simples 0,6-1 mm compr., base não alargada, sinuosos, e furfuráceo-estrelado sobre as nervuras principais. Panículas $7,5-16,5 \mathrm{~cm}$ compr.; brácteas $0,8-1,2 \mathrm{~mm}$ compr., bractéolas 0,7-1 mm compr. Flores 5-meras; hipanto 2,5$4 \mathrm{~mm}$ compr; cálice com tubo $0,2-0,4 \mathrm{~mm}$ compr., lacínias internas $0,3-0,6 \mathrm{~mm}$ compr., triangulares, lacínias externas $1-1,7 \mathrm{~mm}$ compr., lineares/cilíndricas; pétalas 2-2,5 mm compr.; estames 10, conectivo inapendiculado, antera 1,3-2,6 mm compr., amarela; ovário 1,5-2 mm compr., 3-locular, ápice com tricomas simples. Frutos 5-9 $\times 4-8 \mathrm{~mm}, 280$ 320 sementes, $0,5-0,8 \times 0,3-0,5 \mathrm{~mm}$.

Material selecionado: Adrianópolis, 23.XI.2004, fl., J. Silva 4215 (MBM). Almirante Tamandaré, 2.VII.1989, fl., O. Ribas 142 (MBM, UPCB). Antonina, 27.IX.1979, bot., L. Dombrowski 10764 (MBM). Arapoti, 17.XI.1989, fr., J. Motta 1718 (MBM, UPCB). Bituruna, 20.VIII.2003, bot., D. Liebsch s.n. (MBM). Bocaiúva do Sul, 12.IX.1973, fl. e fr., G Hatschbach 32534 (MBM). Campina Grande do Sul, 17.X.2005, fl., R. Goldenberg 711 (UPCB). Carambeí, 1.XI.1999, bot., A. Dunaiski 1433 (MBM). Cerro Azul, 3.X.1973, fl., G. Hatschbach 32619 (MBM). Céu Azul, 10.VIII.1997, bot., $M$. Sobral 8582 (MBM). Curitiba, 17.IX.1999, fl., A. Cervi 6777 (UPCB). Dr. Ulysses, 7.X.1999, fl., G. Hatschbach 69305 (MBM). Guarapuava, 15.VIII.2004, fr., J. Cordeir 50 (UPCB). Guaratuba, 15.X.1997, fl., E. Santos 319 (MBM). Imbaú, 23.IX.1994, fr., V. Кinnup 99 (FUEL, MBM). Irati, 29.XII.2004, bot., D. Saveressig 334 (UPCB). Mangueirinha, 20.X.1966, bot., G. Hatschbach 15168 (MBM). Matelândia, 2.XII.1966, fr., J. Lindeman 3564 (MBM). Medianeira, 23.X.1969, fl., G. Hatschbach 22617 (MBM). Morretes, 9.III.2000, A. Pasdiora 76 (UPCB). Paranaguá, 22.X.1971, fl., G. Hatschbach 27561 (MBM). Pinhão, 15.III.1967, fr., J. Lindeman 4909 (MBM). Piraí do Sul, 2.XI.1998, fr., O. Ribas 2795 (MBM, UPCB). Piraquara, 10.XII.2004, fr., M. Reginato 124 (UPCB). Ponta Grossa, s.d., bot., G. Gatti 178 (UPCB). Prudentópolis, 19.X.1963, fl., G. Hatschbach 9318 (MBM). Pitanga, 18.X.1973, bot., G. Hatschbach 32850 (MBM, UPCB). Quatro Barras, 21.VII.1996, bot., A. Schutz 66 (UPCB). Rio Branco do Sul, 13.IX.1996, fl., G. Tiepolo 680 (MBM). São José dos Pinhais, 27.X.2003, fl., J. Silva 3776 (MBM). São Mateus do Sul, 16.IX.1986, fl., R. Britez 894 (MBM). Sapopema, 8.XI.1997, fr., C. Medri 524 (FUEL, UPCB). Tibagi, 5.XII.2003, fr, M. Carmo 520
(UPCB). Tijucas do Sul, 2.X.2002, fl., D. Liebsch 392 (UPCB). Tomazina, 17.IX.1993, fl., G. Hatschbach 59373 (MBM). Três Barras do Paraná, 16.X.1997, fl. e fr., J. Silva 2143 (MBM). Tunas do Paraná, 17.X.2005, fl., R. Goldenberg 739(UPCB). Distribuição: Minas Gerais, São Paulo, Paraná, Santa Catarina e Rio Grande do Sul. No Paraná ocorre em todas as regiões geomorfológicas e fitogeográficas do estado.

Leandra regnellii pode ser reconhecida pelas folhas normalmente grandes (até $23 \mathrm{~cm}$ compr.), com $5+2$ a $7+2$ nervuras longamente suprabasais. Apresenta grande variação morfológica, incluindo hábito da planta, tipo e densidade de tricomas, além do número de nervuras presentes na lâmina foliar. Coletada com flores em praticamente todos os meses do ano, com frutos em março, e entre agosto e dezembro.

35. Leandra reitzii Wurdack, Sellowia 14:196. 1962. Sect. Oxymeris.

Fig. 2-a

Arbustos a arvoretas 2-5 m alt. Ramos jovens cilíndricos a levemente achatados, glabros a esparsamente furfuráceo-estrelados. Folhas com pecíolos 0,8-2,2 cm compr.; lâmina 3,8-13×1-4,5 cm, cartácea, elípticas a elípticalanceoladas, ápice agudo, margem lisa, base obtusa, nervuras 3 a $3+2$ curtamente suprabasais; faces adaxial e abaxial glabras, tricomas simples na base das nervuras primárias. Panículas $2-$ $13 \mathrm{~cm}$ compr.; brácteas folhosas, 2,8-8,8 mm; bractéolas folhosas 1,3-4 mm. Flores 5-meras; hipanto 3-4 mm compr.; cálice com tubo 0,30,5 mm compr., lacínias internas $0,5-1,2 \mathrm{~mm}$ compr., largamente triangulares, lacínias externas 2-3,3 mm compr., estreitamente triangulares; pétalas 3-4 $\mathrm{mm}$; estames 10 , conectivo inapendiculado, antera $2-3 \mathrm{~mm}$ compr., alva; ovário 1,8-2,5 mm, 3-locular, ápice glabro ou com tricomas simples. Frutos 5-6×4,5-5,2 mm, ca. 200 sementes, $1 \times 0,4-0,6 \mathrm{~mm}$.

Material selecionado: Antonina, I.1993, fl., G. Hatschbach 58523 (MBM). Bocaiúva do Sul, V.2004, fr., J. Cordeiro 2168 (MBM). Guaratuba, I.2004, fl., J. Silva 3970 (MBM). Morretes, 26.X.2005, fl., R. Goldenberg 811 (UPCB). Quatro Barras, 12.IV.1989, fr., J. Silva 585(UPCB). Piraquara, 22.X.2005, fl., R. Goldenberg 788 (UPCB). 
Distribuição: Paraná e Santa Catarina. No Paraná ocorre Litoral, Serra do Mar e Primeiro Planalto, em FD montana e submontana, e também em refúgios vegetacionais.

Esta espécie pode ser reconhecida pelas folhas oblongas ou oblongo-lanceoladas, com até $13 \mathrm{~cm}$ compr., face adaxial glabra e face abaxial com tricomas simples na base das nervuras principais. Pode ser confundida com $L$. quinquedentata (ver comentários) e $L$. sulfurea, que difere pelas folhas e ramos com indumento furfuráceo-estrelado, lacínias do cálice caducas no fruto. Espécie citada por Wurdack (1962) como endêmica de Santa Catarina. Coletada com flores entre outubro e fevereiro, com frutos em abril e maio, e também em novembro.

36. Leandra reversa (DC.) Cogn. in Mart. \& Eichler, Fl. bras. 14(4): 198. 1886. Sect. Secundiflorae.

Fig. $2 p, 3 c$

Arbustos a arvoretas 1-2,5 m alt. Ramos jovens cilíndricos, achatados a sulcados, densamente glanduloso-pubescentes, tricomas simples 1,8-3,8 mm compr., com base não alargada, glândula apical caduca ou não. Folhas com pecíolos 1,8-5,2 cm compr.; lâmina 8-21 $\times$ 4-10,5 cm, membranácea, oval, ápice acuminado, raro agudo, margem denticulada, base obtusa a cuneada, nervuras $5+2$ a $7+2$ basais; face adaxial densamente estrigosa, tricomas simples 1,5-2 mm compr., base levemente alargada, levemente adpressos, face abaxial densamente glanduloso-pubescente, tricomas simples 1,2-1,8 mm compr., base não alargada, glândula apical caduca. Panículas escorpióides 7-14,5 cm compr.; brácteas 27,5 mm compr., bractéolas $1-1,5 \mathrm{~mm}$ compr. Flores 5-meras; hipanto 2,4-3,2 mm compr.; cálice com tubo $0,2 \mathrm{~mm}$ compr., lacínias internas $0,3-0,5 \mathrm{~mm}$ compr., largamente triangulares, lacínias externas $0,7-1 \mathrm{~mm}$ compr., lineares; pétalas 2,5-3,5 mm compr.; estames 10 , conectivo inapendiculado, antera 1,4-1,8 mm compr., amarela; ovário 1,6-2 mm compr., 5-locular, ápice com tricomas glandulares. Frutos 6,5-7,5 × 5,8-6,5 mm, sementes ca. $0,3 \times 0,2 \mathrm{~mm}$.
Material selecionado:Adrianópolis, 18.X.2005, bot., R. Goldenberg 756(UPCB). Antonina, 28.VI.2007, fl., E. Camargo 145 (UPCB). Guaraqueçaba, 8.XII.2004, fl., R. Goldenberg 672 (UPCB). Morretes, 3.X.1999, fl., A. Pasdiora 54 (UPCB).

Distribuição: Piauí, Bahia, Minas Gerais, Espírito Santo, Rio de Janeiro, São Paulo, Paraná e Santa Catarina. No Paraná, ocorre no Litoral, Serra do Mar e Primeiro Planalto, em FD (Terras Baixas, Submontana e Montana) e transição FD-FOM.

Leandra reversa pode ser reconhecida pelas folhas ovais, com $5+2$ a $7+2$ nervuras basais, com indumento denso, inflorescências escorpióides, com indumento avermelhado, glanduloso-pubescente, e é a única espécie no Paraná que apresenta sementes ovais, com superfície tuberculada. Assemelha-se em parte a $L$. regnellii, pelas folhas membranáceas, ovais e pelas inflorescências avermelhadas e estames amarelos, mas difere pelas nervuras claramente basais e pela forma da inflorescência. Coletada com flores de outubro a janeiro, e entre junho e agosto, com frutos entre abril e agosto e em dezembro.

37. Leandra riograndensis (Brade) Wurdack, Sellowia 14: 205. 1962. Sect. Chaetodon.

Fig. $1 \mathrm{j}$

Subarbustos $0,3-0,7 \mathrm{~m}$ alt. Ramos jovens cilíndricos, densamente estrigosos, tricomas simples 1-2,3 mm compr., com base levemente alargada, adpressos. Folhas com pecíolos 0,21,4 cm compr.; lâmina 2,3-6,5 × 1-3,5 cm, membranácea, oval, ápice agudo, margem lisa, base obtusa a cordada, 5 nervuras basais, nervuras secundárias oblíquas em relação às principais; face adaxial densamente estrigosa, tricomas simples $0,4-1,5 \mathrm{~mm}$ compr., base levemente alargada, levemente adpressos a eretos, face abaxial densamente estrigosa, tricomas simples 0,5-1,5 mm compr., base levemente alargada, levemente adpressos a eretos, e tricomas simples adpressos ao longo das nervuras principais e secundárias. Panículas 1-2,8 cm compr.; brácteas $1-1,7$ mm compr.; bractéolas $1 \mathrm{~mm}$ compr. Flores 5-meras; hipanto 2,7-4 mm compr.; cálice com tubo $0,2-0,3 \mathrm{~mm}$ 
compr., lacínias internas 0,3-0,5 mm compr., curtamente triangular, lacínias externas 1,21,6 mm compr., estreitamente oblongas; pétalas 1,8-2 mm compr.; estames 10, conectivo inapendiculado, antera $1-1,2 \mathrm{~mm}$ compr.; ovário 1,6-1,8 mm compr., 4-locular, com tricomas no ápice. Frutos 2,5-3,6 $2-2,5 \mathrm{~mm}$, $120-150$ sementes, $0,7-0,8 \times 0,3-0,5 \mathrm{~mm}$.

Material selecionado: Almirante Tamandaré, IV.1974, fr., L. Dombrowski 5151 (MBM). Cerro Azul, I.1974, fl., G. Hatschbach 33774 (MBM). Colombo, II.1972, fl., L. Dombrowski 4052 (MBM). Curitiba, I.1967, fr., T. Caproglione s.n.(UPCB 6860). Quatro Barras, I.1974, fl. e fr., G. Hatschbach 33629 (MBM). Piraquara, X.2005, fl., R. Goldenberg s.n (UPCB 52085). São José dos Pinhais, X.1998, fl., $O$. Ribas 2749 (MBM). São Mateus do Sul, X.1986, bot. e fl., R. Britez 989 (MBM). União da Vitória, XII.1967, fl. e fr., C. Koczicki 49 (MBM).

Distribuição: Paraná, Santa Catarina e Rio Grande do Sul. No Paraná, ocorre no Primeiro e Terceiro Planaltos, em FOM.

Esta espécie pode ser reconhecida pelas folhas ovais, com base obtusa a cordada e 5 nervuras basais. A face abaxial possui nervuras laterais oblíquas às principais, estas revestidas por tricomas simples adpressos. Coletada com flores entre outubro e fevereiro, com frutos entre dezembro e abril.

38. Leandra salicina (DC.) Cogn. in Mart. \& Eichler, Fl. bras. 14(4): 150. 1886. Sect. Carassanae.

Fig. $2 \mathrm{i}$

Subarbustos a arbustos, $0,3-0,8 \mathrm{~m}$ alt. Ramos jovens cilíndricos, densamente seríceos, tricomas simples 1,4-2,4 mm compr., com base levemente alargada, adpressos. Folhas com pecíolos 0,3-1,2 cm compr.; lâmina 3,2-9,5× 0,5-1,3 cm, cartácea, linear, ápice agudo a acuminado, margem lisa, base cuneada, nervuras 3 basais; face adaxial glabra, face abaxial esparsamente serícea, tricomas simples 1,3-1,7 mm compr., base levemente alargada, adpressos, esparsos na superfície e denso sobre as nervuras principais. Panículas 3-5 cm compr.; brácteas 3,2-6 $\mathrm{mm}$ compr., bractéolas 2-4 mm compr. Flores 4-5-meras; hipanto 34,5 mm compr.; cálice com tubo $0,2-0,3 \mathrm{~mm}$ compr., lacínias internas $0,5-0,7 \mathrm{~mm}$ compr., triangulares a oblongas, lacínias externas 1,2$2 \mathrm{~mm}$ compr., lineares; pétalas 3,5-4,2 $\mathrm{mm}$ compr; estames 8-10, conectivo com apêndice dorsal curto, antera 2-2,4 mm compr., amarela; ovário 1,4-2,5 mm compr., 3-4-locular, ápice glabro. Frutos $7-8,5 \times 4-4,8$, ca. 120 sementes, $0,8-0,9 \times 0,4-0,5$.

Material selecionado: Campo Largo, 18.XII.1960, fl., G. Hatschbach 7581 (MBM, UPCB). Jaguariaíva, 21.XII.1961, fl., G. Hatschbach 8682 (HBR, MBM). Ponta Grossa, 12.III.1999, fr., $R$. Goldenberg 501 (UPCB). Sengés, 8.VII.1995, bot., U. Albino s.n. (FUEL 22078). Tibagi, 15.I.2004, fl., M. Carmo 631 (UPCB). Distribuição: Minas Gerais, São Paulo e Paraná. Neste Estado ocorre no Segundo Planalto, em CA e CE, sempre na margem de cursos d'água, em regiões com afloramentos de arenito.

Esta espécie pode ser reconhecida principalmente pelas folhas lineares, com pecíolo curto $(0,3-1,2 \mathrm{~cm}$ compr). Tanto em herbários paranaenses quanto de outros Estados, a mesma espécie é frequentemente determinada como $L$. parvifolia $\operatorname{Cogn}$. e $L$. linearifolia Cogn. Cogniaux (1886-1888) descreveu L. linearifolia com bractéolas densamente hirsutas, e lacínias externas do cálice com ápice obtuso/arredondado, enquanto as outras duas espécies possuiriam bractéolas glabras ou esparsamente estrigosas e lacínias externas do cálice com ápice acuminado ou aristado. Segundo Cogniaux (1886-1888), $L$. salicina possuiria bractéolas lineares a subuladas, com indumento esparso, e $L$. parvifolia possuiria bractéolas lanceoladas e glabras. Visto que os espécimes analisados possuem características intermediárias entre L. salicina e L. parvifolia, optou-se por considerar apenas uma espécie como ocorrente no Estado, sendo L. salicina o nome mais antigo. Coletada com flores em dezembro e janeiro, com frutos em fevereiro e março.

39. Leandra sulfurea (Naudin) Cogn. in Mart. \& Eichler, Fl. bras. 14(4): 153. 1886. Sect. Oxymeris. Fig. 2d

Subarbustos a arbustos, 0,3-1 m alt. Ramos jovens cilíndricos a levemente achatados, moderada a densamente furfuráceo-estrelados. 
Folhas com pecíolos 0,5-1,8 cm compr.; lâmina 3-7 × 1,4-3,8 cm, coriácea ou subcoriácea, elíptica a oval, ápice agudo a acuminado, margem revoluta, base obtusa, nervuras 3 a $3+2$ curtamente suprabasais; face adaxial glabra, face abaxial moderada a densamente furfuráceo-estrelada. Panículas 2,5-8,2 cm compr.; brácteas folhosas $6,7-7,5 \mathrm{~mm}$; bractéolas folhosas 3-5,5 mm. Flores 5-meras; hipanto 3,5-5 mm compr; cálice com tubo 0,40,6 mm compr., lacínias internas 1-2 mm compr., triangulares a oblongas, lacínias externas 1,3-2,2 mm compr., cilíndricas; pétalas 5-5,7 $\mathrm{mm}$; estames 10 , conectivo inapendiculado, antera 2,5-2,8 $\mathrm{mm}$ compr., rósea; ovário 2-2,5 mm, 3-locular, ápice glabro ou com tricomas simples. Frutos 6,5-7,5 ×5,5 $\mathrm{mm}$, cerca de 200 sementes, $1-1,2 \times 0,7 \mathrm{~mm}$. Material selecionado: Antonina, 10.III.2001, fl., $M$. Scheer 246 (MBM, UPCB). Campina Grande do Sul, 24.X.2005, bot., R. Goldenberg 798 (UPCB).

Distribuição: Minas Gerais, Rio de Janeiro, São Paulo, Paraná e Santa Catarina. No Paraná ocorre na Serra do Mar e áreas altas do Primeiro Planalto, principalmente em FD montana e altomontana.

Esta espécie pode ser reconhecida pelos ramos e face abaxial das lâminas com indumento furfuráceo-estrelado, e pelas folhas coriáceas, com a face adaxial glabra. As brácteas são folhosas, e as lacínias do cálice são caducas no fruto. Ver comentários em $L$. reitzii e L. quinquedentata. Coletada com flores entre dezembro e março, com frutos entre junho e outubro.

40. Leandra tetraquetra (Cham.) Cogn. in Mart. \& Eichler, Fl. bras. 14(4): 112. 1886. Sect. Carassanae. Fig. 1t, 3k

Arbustos a arvoretas, 1,5-3,5 $\mathrm{m}$ alt. Ramos jovens quadrangulares, densamente recobertos por tricomas dendríticos 0,8-1,5 mm compr., com eixo alargado. Folhas com pecíolos 2-6,5 cm compr.; lâmina 10-19×4,5$9,5 \mathrm{~cm}$, cartácea, oval, ápice agudo a acuminado, margem denticulada, base cordada, nervuras $5+2$ basais, às vezes curtamente suprabasais; face adaxial densamente escabrosa, tricomas simples 0,5-0,8 mm compr., base alargada, adpressos, face abaxial densamente recoberta com tricomas estrelado-estipitados, 0,3-0,5 mm compr., eixo não alargado. Panículas 8$11,5 \mathrm{~cm}$ compr.; brácteas 2,5-3 mm compr., bractéolas 1,5-1,8 mm compr. Flores 5-meras; hipanto 2,8-3,5 mm compr.; cálice com tubo 0,3-0,5 mm compr., lacínias internas 0,8-1,3 $\mathrm{mm}$ compr., triangulares, lacínias externas 22,3 mm compr., lineares; pétalas 2,5-3 mm compr.; estames 10, conectivo inapendiculado, antera 2,2-2,6 mm compr., rósea; ovário 1,5$2 \mathrm{~mm}$ compr., 3-locular, ápice com tricomas simples. Frutos não vistos.

Material selecionado: Antonina, 26.VI.2007, fl., e fr., E. Camargo 138 (UPCB). Morretes, 26.X.2005, fl., R. Goldenberg 807 (UPCB).

Distribuição: Minas Gerais, Rio de Janeiro, São Paulo e Paraná. Neste estado, ocorre na Serra do Mar, em FD Altomontana, Montana e Submontana.

Leandra tetraquetra pode ser reconhecida pela presença de ramos de formato quadrangular, face adaxial das folhas escabrosas e a face abaxial com tricomas estrelados-estipitados. Espécie coletada apenas recentemente no estado, a partir de 2005. Coletada com flores em junho, e entre outubro e dezembro, e com frutos em junho.

41. Leandra xanthocoma (Naudin) Cogn. in Mart. \& Eichler, Fl. bras. 14(4): 124. 1886. Sect. Niangae.

Fig. 21, 3i

Subarbustos a arbustos 0,5-1,5 m alt. Ramos jovens cilíndricos, esparsamente furfuráceo-estrelados e moderada a densamente estrigosos a hirsutos, tricomas simples 1,8-3 $\mathrm{mm}$ compr., com base levemente alargada, eretos. Folhas com pecíolos 0,8-3,6 cm compr.; lâmina 4-12×2-6,5 cm, membranácea, oval a elíptica, ápice acuminado, raro agudo, margem lisa a denticulada, base obtusa, raro cuneada, nervuras 5 curtamente suprabasais; face adaxial moderada a densamente estrigosa, tricomas simples 1,7-2,2 mm compr., base levemente alargada, eretos, face abaxial esparso a moderadamente pubescente, tricomas simples $0,8-1,2 \mathrm{~mm}$ compr., base não 
alargada, sinuosos, e moderado a densamente furfuráceo-estrelado. Panículas 5-11 cm compr.; brácteas 2-3 mm compr., bractéolas 0,8-1,5 mm compr. Flores 5-meras; hipanto 5-6,5 mm compr; cálice com tubo 0,4-0,5 mm compr., lacínias internas 1,2-1,8 mm compr., triangulares, lacínias externas 2,5-4 $\mathrm{mm}$ compr., lineares ou estreitamente triangulares; pétalas 3,8-4,5 mm compr; estames 10, conectivo inapendiculado, antera 4,5-5 mm compr., amarela; ovário 2-3 mm compr., 4-locular, ápice glabro. Frutos 7-8 $\times$ 5-6,7 mm, 240-260 sementes, 0,7-0,9 × 0,5$0,6 \mathrm{~mm}$.

Material selecionado:Adrianópolis, 12.XII.2006, fl., E. Camargo 59(UPCB). Arapoti, 22.I.1990, bot., J. Motta 1795 (MBM). Balsa Nova, 10.XII.1978, bot., L. Dombrowski 9313 (MBM). Bituruna, 18.XII.2003, fl., D. Liebsch s.n. (MBM 299374). Bocaiúva do Sul, 25.XI.2006, fl., E. Camargo(UPCB). Campina Grande do Sul, 2.XII.1962, fl., G. Hatschbach 9531 (MBM). Campo Largo, 17.XI.1996, fl., G. Tiepolo 399(MBM). Campo Mourão, 4.VII.2003, fl., M. Caxambu 60 (MBM). Chopinzinho, 19.II.1971, bot., G. Hatschbach 26361 (MBM, UPCB). Colombo, 29.IX.2004, fl., R. Possette 77 (MBM). Curitiba, 21.XI.2007, fl., E. Camargo 153 (UPCB). Dois Vizinhos, 11.VIII.1968, bot., G. Hatschbach 19388 (MBM). Foz do Iguaçu, 15.XII.1992, bot., A. Cervi 3892 (MBM). Guarapuava, 17.III.2003, fl., C. Kozera 1945 (UPCB). Imbituva, 6.II.1969, fl., G. Hatschbach 20984 (MBM). Irati, 16.XII.1977, fl., G. Hatschbach 40633 (MBM). Lapa, 13.XI.1999, fl., J. Cordeiro 1590 (MBM). Laranjeiras do Sul, 7.III.1967, fl., J. Lindeman 4670 (MBM). Marmeleiro, 21.II.1971, bot., G. Hatschbach 26431 (MBM). Medianeira, 23.X.1969, fl., G. Hatschbach 22614 (MBM). Morretes, 2.XII.1971, fl., L. Dombrowski 3938 (MBM). Palmeira, 6.V.1973, fl., G. Hatschbach 31850 (MBM). Piraquara, 1.IV.2006, fl., E. Camargo 15 (UPCB). Porto Vitória, 8.XII.1971, fl., G. Hatschbach 28376 (MBM). Rio Branco do Sul, 13.XII.1996, fl., G. Tiepolo 645 (MBM). São João do Triunfo, 7.XI.1967, fl., G. Hatschbach 17721 (MBM). São José da Boa Vista, 19.XI.1970, bot., G. Hatschbach 25536 (MBM, UPCB). São José dos Pinhais, 14.XII.1971, fl., L. Dombrowski 3875 (MBM). São Mateus do Sul, 22.IV.1986, fl., R. Britez 529 (MBM). Tamarana, 24.XI.1992, bot., N. Marquesini s.n. (MBM). Tijucas do Sul, 8.I.2002, fl., D. Liebsh 394 (MBM). Tunas do Paraná, 21.IV.2007, fr., E. Camargo 93 (UPCB). União da Vitória, 15.XI.1998, fl., G. Hatschbach 68674 (MBM, UPCB).
Distribuição: Minas Gerais, Rio de Janeiro, São Paulo, Paraná e Santa Catarina. No Paraná ocorre na Serra do Mar e nos três planaltos paranaenses, em praticamente todas as regiões fitogeográficas do estado.

Leandra xanthocoma caracteriza-se pelas folhas com nervuras curtamente suprabasais, estames grandes (anteras com até 5 mm compr.) e 4 lóculos no ovário. Assemelhase muito a $L$. australis (ver comentários) e a L. xanthostachya, que diferem pelas panículas mais desenvolvidas e ramificadas, estames menores e flores com lacínias externas do cálice menores do que as lacínias internas. Cogniaux (1886-1888) incluiu esta espécie na seção Carassanae, mas pelo conjunto de características apresentadas (indumento dos ramos hirsuto, ápice do ovário glabro), sugerese a transferência de L. xanthocoma para a seção Niangae. Coletada com flores e frutos em praticamente todos os meses do ano.

42. Leandra xanthostachya Cogn. in Mart. \& Eichler, Fl. bras. 14(4): 93. 1886. Sect. Niangae.

Fig. 1o, 3e

Subrbustos a arbustos, 0,7-2 m alt. Ramos jovens cilíndricos, densamente hirsutos, tricomas simples 2-4,2 mm compr., com base levemente alargada, eretos. Folhas com pecíolos 1-4,3 cm compr.; lâmina 6,5-17,5×2,5-6 cm, cartácea, lanceolada a oval-lanceoladas, ápice acuminado, margem lisa a denticulada, base obtusa a cuneada, nervuras 5+2 suprabasais; face adaxial esparsamente estrigosa, tricomas simples 0,8-1,8 mm compr., base levemente alargada, levemente adpressos, face abaxial esparsa a moderadamente pubescente, tricomas simples $0,8-1,2 \mathrm{~mm}$ compr., base levemente alargada, sinuosos, e moderada a densamente furfuráceo-estrelada. Panículas 12-21,5 cm compr; brácteas 1,5-7 mm compr., bractéolas 0,7-1 mm compr. Flores 5-meras; hipanto 4-5,2 mm compr.; cálice com tubo 0,5 mm compr., lacínias internas 2-3 mm compr., oblongas, ápice arredondado, lacínias externas 1,3-1,6 mm compr., lineares/cilíndricas; pétalas 3,5-4,5 mm compr.; estames 10, conectivo inapendiculado, antera 2,4-3 mm compr., 
amarela; ovário 1,8-2,6 mm compr., 3-locular, ápice glabro. Frutos 6-7 ×5-6 mm, 200-250 sementes, $0,7-0,8 \times 0,5-0,6 \mathrm{~mm}$.

Material selecionado:Adrianópolis, 12.XII.2006, fr., E. Camargo 72 (UPCB). Bocaiúva do Sul, 28.XII.1994, bot., G. Hatschbach 61393 (MBM). Campina Grande do Sul, 12.XI.1968, fl., G Hatschbach 20302 (MBM). Ponta Grossa, 12.X.1995, bot., C. Poliquese s.n. (MBM 188550). Tunas do Paraná, 17.X.2005, fl., R. Goldenberg 738 (UPCB).

Distribuição: Minas Gerais, Espírito Santo, Rio de Janeiro, São Paulo, Paraná e Santa Catarina. No Paraná, ocorre no Primeiro e Segundo Planaltos, em transição FOM-FD e CA.

Esta espécie pode ser reconhecida pelas folhas lanceoladas, raro oval-lanceoladas, com base cuneada a obtusa e nervuras $5+2$ suprabasais. As lacínias externas do cálice são menores do que as internas, ao contrário das outras espécies da seção. Ver comentários em L. xanthocoma. Coletada com flores de outubro a dezembro, com frutos em dezembro.

\section{Leandra sp.}

Fig. 1r

Arbustos 1,5 m alt. Ramos jovens cilíndricos, esparsamente furfuráceoestrelados e moderadamente pubescentes, tricomas simples 1-1,4 mm compr., com base não alargada, sinuosos. Folhas com pecíolos 2,9-4,5 cm compr., lâmina 9,5-13,5×4-7 cm, membranácea, oval, ápice acuminado, margem lisa, base obtusa a levemente cordada, nervuras $5+2$ curtamente suprabasais; face adaxial moderada a densamente estrigosa, tricomas simples 1,2-1,8 mm compr., base levemente alargada, levemente adpressos, face abaxial moderadamente pubescente, tricomas simples 0,5-0,8 mm compr., base não alargada, sinuosos, e esparsa a mderadamente furfuráceoestrelada. Panículas 10,5 cm compr; brácteas 1,2-1,5 mm compr. Flores 5-meras; hipanto 3,2-4 mm compr.; cálice com tubo 0,2-0,3 mm compr., lacínias internas $0,5-0,7$ mm compr., triangulares, lacínias externas 1,3-1,8 mm compr., lineares; pétalas 2,5-3 mm compr.; estames 10, conectivo inapendiculado, antera 2-2,5 mm compr., rósea; ovário 2-2,5 mm compr., 3-4 locular, ápice com tricomas simples. Frutos não vistos.
Material selecionado: Palmeira, 23.IX.1962, fl., G. Hatschbach 10169 (MBM).

Este espécime estava inicialmente determinado por J. J. Wurdack comoLeandra cf. miconiastrum (Naudin) Cogn. Cogniaux (1886-1888) descreveu esta espécie com ramos glabros ou esparsamente pubescentes, folhas curtamente pecioladas, oblongolanceoladas, face adaxial glabra e 5 nervuras curtamente suprabasais, e hipanto furfuráceo. Este conjunto de características demonstra que o espécime aqui considerado Leandra sp. não possui afinidade ou semelhança com $L$. miconiastrum., mas também não foi possível identificá-lo.

\section{Agradecimentos}

A Gerdt Hatschbach e equipe do MBM, assim como os curadores dos demais herbários (FUEL e HUPG) que permitiram o empréstimo das exsicatas; aos herbários R, RB e SP pela permissão de visita às coleções e tipos das espécies; a Diana Carneiro pelas ilustrações; e a Rosana Romero e Ana Odete Vieira pelas correções e sugestões. O primeiro autor recebeu bolsa do Programa Taxonomia (Mestrado) do CNPQ, e o segundo autor recebe bolsa produtividade CNPQ.

\section{REFERÊNCIAS BIBLIOGRÁFICAS}

AmbienteBrasil. Informações sobre o estado do Paraná. Disponível em: <http:// www.ambientebrasil.com.br.>. Acesso em: 20/06/2007.

Camargo, E. A. \& Goldenberg, R. 2007. O gênero Leandra, seção Leandraria (Melastomataceae) no Paraná. Iheringiasérie Botânica 62(1): 105-113.

Clausing, G. \& Renner, S. S. 2001. Molecular phylogenetics of Melastomataceae and Memecylaceae: implications for character evolution. American Journal of Botany 88(3): 486-498.

Cogniaux, A. 1886-1888. Melastomataceae. Miconieae. In: Martius, C. F. P.; Eichler, A. G. \& Urban, I. (eds.). Flora brasiliensis 14(4): 64-558. 
Cogniaux, A. 1891. Melastomataceae. In: De Candolle, A.; De Candolle, C. (eds.). Monographiae Phanerogamarum. 7: 1-1256.

Goldenberg, R. 2004. O gênero Miconia (Melastomataceae) no estado do Paraná. Acta Botanica Brasilica18(4): 927-947.

Goldenberg, R.; Souza, C. M. F. \& Dequech, H. B. 2005. Clidemia, Ossaea e Pleiochiton (Melastomataceae) no estado do Paraná, Brasil. Hoehnea 32(3): 453-466.

Judd, W. S. \& Skean, J. D. 1991. Taxonomic studies in the Miconiae (Melastomataceae). IV. Generic realignements among terminalflowered taxa. Bulletin of the Florida Museum of Natural History, Biological Sciences 36(2): 25-84.

Judd, W. S. 1986. Taxonomic studies in the Miconieae (Melastomataceae). I. Variation in inflorescence position. Brittonia 38(2): 150-161.

Lawrence, G. H. M. 1951. Taxonomy vascular plants. The Macmillan Company. 179p.

Leite, P. F. 1994. As diferentes unidades fitoecológicas da Região Sul do Brasil; proposta de classificação. Dissertação de Mestrado. Universidade Federal do Paraná, Curitiba. 160p.

Maack, R. 1968. Geografia física do estado do Paraná. BADEP/UFPR/IBTP, Curitiba. 350p.
Martin, C. V.; Little, D. P.; Goldenberg, R. \& Michelangeli, F. A. 2008. A preliminary phylogenetic analysis of the polyphyletic genus Leandra (Miconieae, Melastomataceae). Cladistics 24: 315-327.

Michelangeli, F. A.; Penneys, D. S.; Giza, J.; Soltis, D.; Hils, M. H. \& Skean, J. D. 2004. A preliminary phylogeny of the tribe Miconiae (Melastomtaceae) based on $n r$ ITS sequence data and its implications on inflorescence position. Taxon 53 (2): 279-290.

Renner, S. S. 1993. Phylogeny and classification of the Melastomataceae and Memecylaceae. Nordic Journal of Botany 13(5): 519-540.

Roderjan, C. V.; Kunyoshi, Y. S; Galvão, F. 1993. As regiões fitogeográficas do estado do Paraná. Acta Forestalia Brasiliensis 1: 3-6.

Souza M. L. \& Baumgratz, J. F. 2004. Notas taxonômicas em Leandra Raddi (Melastomataceae). Insula, Florianópolis 33: 89-99.

The New York Botanical Garden. Index Herbariorum. Disponível em: <http://sciweb. nybg.org/science2/IndexHerbariorum.asp $>$. Acesso em: 15/04/2007.

Wurdack, J. J. 1962. Melastomataceae of Santa Catarina. Sellowia 14: 109-217.

Wurdack, J. J. 1970. Certamen Melastomataceis XV. Phytologia 20: 369-389.

\section{Lista de Coletores}

Abe,L.: 402 (23); 2604 (11); 4224 (16); Albino,U.:FUEL 22078(38);Andrade,S.F.:09(2);Antunes,M.: FUEL 6418 (6); Athayde, S.: 288 (3); Barbosa, E.: 393 (12); 402 (23); 544 (34); Berg, G.A.: FUEL28933 (2); Bidá,A.: 131 (11); 252 (3); Brade,A.: 19501 (13); 19531 (6); 19655 (41); 19665 (41);Braga, R.: 4 (25); 509 (13); UPCB 852 (3);Britez, R.M.: 152 (33); 527 (6); 529 (41); 894 (34); 989 (37); 1793 (8); Camargo, E.: 3 (41); 4(41); 5 (24); 7(24); 8 (23); 10 (6); $11(6) ; 15(41) ; 20(25) ; 21(4) ; 35(6) ; 36(6) ; 37(41) ; 39(41) ; 40(41) ; 41(3) ; 42(3) ; 43(6) ; 45(6) ; 54(41) ; 55(41) ; 57$ (8); $58(8) ; 59(41) ; 62$ (17); $63(8) ; 65(6) ; 66(10) ; 67(11) ; 69(12) ; 70(10) ; 72(42) ; 74(3) ; 75(6) ; 76(10) ; 77(13) ; 85$ (3); $86(4) ; 92$ (6); $93(3) ; 94(6) ; 96(6) ; 98(14) ; 112(31) ; 114(10) ; 115(10) ; 119(8) ; 124(32) ; 130(10) ; 133(40) ; 136$ (40); 137 (14); 138 (40); 145 (36); 150(7); 151 (7); 152 (13); 153 (41); 154(3); 155 (26); $156(26) ; 157$ (26); $158(26) ; 161$ (30); 162 (2); 163 (30); 167 (2); 168 (2); 172 (30); 174 (13); Cândido,L.: 5 (27);Canepagnolo, R.: 378 (23); Capriglioni, T.: 1658(33); UPCB 6860 (37);Carmo,M.: 61 (31); 161 (30);239 (34); 365 (30); 519(31); 520(34); 631 (38); 1168 (30); Carneiro, J.: 531 (34); 555 (34); 753 (31); 1290 (20); Carrião, D.: 41 (2); UPCB 25274 (6); UPCB 28404 (34); UPCB 28406 (33); Cavalini,M.:HUPG 13391 (3); Caxambu,M.G.: 60 (2); 663 (13); 677 (11); UPCB 41917 (11); UPCB 44405 (34); UPCB 44408 (23); UPCB 44805 (24); Cervi,A.C.: 2410 (35); 2414 (3); 2426 (10); 2677 (2); 2882 (26); 2933 (31); 2979 (30); 3017 (11); 3537 (13); 3892 (41); 4005 (26); 4270 (26); 6136 (2); 6156 (2); 6247 (26); 6463 (36); 6534 (36); 6777 (34); 7062 (26); 8301 (23); 8314 (27); 8415 (2); 8530 (31); 8533 (2); 8544 (32); 8554 (23); UPCB 30540 (13); UPCB 
37586 (2); Cordeiro, J.: 50 (34); 68 (6); 340 (4); 389 (11); 1286 (18); 1341 (31); 1590 (41); 1627 (34); 1630 (33); 1968 (13); 2108 (21); 2168 (35); 3261 (19); 3263 (9); Cunha, J.: 197 (3); Dala Rosa, S.: 24 (32); 80 (35); Demarchi, L.F.: FUEL 28838 (6); Dias, M.: FUEL 18008 (30); Diógenes, G.C.: 8 (6); Dittrich, V.: 238 (33); 508 (34); 560 (10); Dombrowski,L.: 662 (30); 894 (2); 902 (13); 999 (13); 1000(30); 1200 (34); 1460 (13); 1462 (30); 1912 (37); 2110(11); 2773 (41); 2893 (6); $2918(30) ; 3652$ (31); $3653(2) ; 3656(34) ; 3660(31) ; 3739(31) ; 3806(6) ; 3812(2) ; 3875(41) ; 3908$ (41); 3909 (34); 3910 (41); 3912 (34); 3913 (34); 3933 (34); 3938 (41); 4051 (41); 4052 (37); 4060 (6); 4312 (34); 4450 (11); 4488 (41); 4541 (11); 4861 (34); $4860(11) ; 4884(34) ; 4890(6) ; 5151$ (37); 5091 (41); 5645 (13); 6357 (6); 6420 (6); 6427 (30); $6428(2) ; 6455(30) ; 6609(6) ; 6777(13) ; 6943(30) ; 6944(13) ; 7012(30) ; 7506(6) ; 9083(30) ; 9206(13) ; 9313$ (41); $9496(30) ; 10476(6) ; 10229$ (34); $10576(2) ; 10455$ (6); $10456(30) ; 10467$ (6); $10584(6) ; 10589(31) ; 10686(30)$; 10695 (30); 10702 (6); 10706 (14); 10708 (6); 10709 (23); 10723 (30); 10725 (34); 10761 (34); $10764(34) ; 10792(13) ;$ 10885 (13); 10982 (10); 10994 (34); 11034 (13); 11153 (13); 11307 (2); 11403 (30); 11446 (6); 11892 (10); 12112 (34); 12221 (11); 13233 (13); 13237 (11); $13378(13) ; 13380$ (30); 13381 (6); 13708 (13); 13839 (6); 13869 (30); $13870(6)$; 14147 (14); 14288 (30); 14302 (11);Dunaiski,A.: 1433 (34);Dusén,P.: 13460 (11);Estevan,D.A.: 128 (6); 184 (2); 467 (31); 468 (2); 546 (3); Falkenberg, F.: 2212 (41); 2214 (6); Ferreira, J.A.: FUEL 30448 (2); Forero, E.: 3756 (11); Gatti, G.: 132(24); 133 (11); 178 (34); 201 (36); 240 (36); 556(3); MBM275897(10); Giongo, C.: 6(34); Goldenberg, R.: 501 (38); $513(4) ; 523(34) ; 538(26) ; 572(4) ; 575(6) ; 666(25) ; 672(36) ; 681(35) ; 689(2) ; 690(29) ; 691(2) ; 695(2)$; 696 (6); 700 (1); $706(12) ; 707$ (33); 708 (8); 709 (10); 711 (34); 712 (3); $726(6) ; 727(6) ; 729(31) ; 731$ (41); $733(23)$; 734 (4); 738 (42); 739 (34); 741 (4); 742 (16); 743 (12); 745 (33); $746(17) ; 755(2) ; 756(36) ; 757$ (31); 788 (35); 789 (6); 790 (25); 791 (17); 794 (28); 795 (32); 796 (18); 798 (39); 799 (19); 800 (32); 801 (21); 806 (29); 807 (40); $811(35) ; 817$ (30); 818 (26); 1030 (21); UPCB 52085 (37); Hara, L.N.: FUEL 28932 (2); Hatschbach, G: 157 (30); 346 (3); 355 (34); 643 (6); 719 (2); 798 (37); $804(3) ; 850$ (33); 1162 (41); $1544(30) ; 3218$ (41); 4067 (25); 4268 (11); $4270(22) ; 4299(32)$; 4891 (6); $5026(34) ; 5040(31) ; 5053(30) ; 5123(2) ; 5168(10) ; 5199(13) ; 5237(1) ; 5238(17) ; 5260(11) ; 5261(33) ; 6807$ (11); 6268 (2); 7104 (12); 7156(12); 7531 (41); 7581 (38); 8009 (6); 8329 (33); 8330 (31); 8447 (9); 8460 (30); 8554(31); 8556 (22); 8670 (12); 8682 (38); 8782 (11); 8987 (2); 9219 (34); $9274(6) ; 9296(8) ; 9316(31) ; 9318(34) ; 9531$ (41); 9684 (10); 10158 (31); 10169 (43); 10271 (33); 10662 (13); 10988 (6); 11092 (9); 11468 (25); $11655(30) ; 11676(2) ; 11678$ (30); 11705 (3); 11706 (31); 11910 (33); 12025 (3); 12029 (37); 12034 (8); $12288(20) ; 12369(10) ; 12772(34) ; 13062$ (23); 13160 (8); 13192 (10); 13453 (41); 13524 (10); 14600 (31); 14654(15); 14935 (31); $15085(23) ; 15168(34) ; 15327$ (33); 15303 (17); 15381 (11); 16443 (6); 16753 (8); 17226 (8); 17312 (28); $17396(30) ; 17593(31) ; 17721$ (41); 17811 (23); 18176(1); $18288(20) ; 18310(41) ; 18415$ (30); 18417 (13); $18533(6) ; 18726(30) ; 18872(2) ; 19388(41) ; 19389(6)$; 19759 (6); 19981 (2); 20270 (34); 20271 (23); 20302 (42); 20306 (12); 20331 (25); 20354 (10); 20739 (3); 20884 (20); 20984 (41); 21682 (12); 21693 (8); 22275 (34); 22521 (9); 22614 (41); 22617 (34); 22736 (33); 22763 (12); 22764 (42); 22842 (11); 23778 (31); 24052 (4); 24461 (2); 24725 (2); 24785 (2); 25343 (30); 25432 (2); 25495 (9); 25497 (31); 25499 (11); 25536 (41); 25595 (31); 25606 (11); 25702 (34); 25712 (33); 25895 (13); 26361 (41);26590 (6); 26769 (2); 27081 (34); 27555 (33); $27558(31) ; 27561$ (34); $27638(11) ; 27649$ (6);27712(30);28159 (13); 28323 (11); $28374(41) ; 28376$ (41);28394 (6); 28496 (11);29349 (10); 29759 (4);29800 (6); 30643 (6); 30708 (7); $30904(34) ; 30980(34) ; 30984(23)$; 31003 (1); 31850 (41); $31860(30) ; 32190(10) ; 32231$ (6); 32534 (34); 32571 (8); $32619(34) ; 32656(31) ; 32682$ (8); 32720 (6); 32734 (30); 32850 (34); 32857 (31); 32946 (11); 33492 (33); 33629 (37); $33650(10) ; 33652$ (20); 33774 (37); 34339 (23); 35431 (2); 35446 (31); 35501 (8); 37313 (31); 37859 (10); 37947 (20); 39799 (10); 39940 (2); $39986(6)$; 39998 (6); 40007 (34); 40400 (23); 40410 (33); 40460 (9); 40633 (41); 41165 (30); 41801 (6); 41811 (23); 41914 (2); 41994 (41); 43234 (23); 43267 (23); 43271 (25); 43333 (9); 43335 (31); 43440 (6); 44469 (10); 45722 (23); 46845 (7); 52532 (23); 52828 (2); $53666(6) ; 54796(33) ; 58234$ (33); 58452 (10); 58523 (35); 59373 (34); 61389 (14); 61391 (41); 61393 (42); 63999 (11); 68300 (2); 68674 (41); 68749 (36); 68824 (23); 68852 (8); 68670 (24); 69305 (34); 69826 (6); 69840 (8); 71340 (23); MBM 4299 (1); MBM 5237 (1); UPCB 4281 (38); UPCB 4292 (34); UPCB 4688 (4); Hertel, R.: 1972 (13); RB 69829 (3); Imaguire, N.: 1073 (34); 1076 (33); 1077 (37); 1080 (33); 2522 (6); 2644 (23); 2946 (6); 3118 (41); 3335 (6); 3482 (23); 5264 (34); 5343 (37); Isernhagen, I.: 213 (36); 215 (10); 224 (3); 243 (10); 302 (41); 327 (1); Ito, E.T.: FUEL 22958 (2); FUEL2801 (2); FUEL 28916(2); FUEL 28918 (26); Kaczmarech, R.: HUPG 11422 (2); Kaeller, M.: 98 (40); 99 (40); Kinnup,V.F.: 99 (34); 649 (2); Koczicki, C.: 9 (41); 49(37); Kozera, C.: 151 (3); 444 (41); 1295 (34); 1296 (23); 1394 (1); 1449 (20); 1945 (34); Krieger,L.: 11184 (1);Kummrow, R.: 7 (34); 51 (6); 335 (41); 341 (41); 735 (3); 875 (41); 881 (11); 895 (30); 1187 (11); 2133 (1); 2401 (9); 2424 (19); 2914 (4); 2974 (34); Kuniyoshi, Y.S.: 17 (6); 111 (34); 320 (34); 822 (34); 823 (41); 1309 (6); 3100 (41); $3106(34) ; 3127$ (33); 3146 (41); 3497 (41); 4299 (6); 4538 (6); 4723 (34); 4767 (12); Labiak, P.: 1919 (34); 1925 (3); 1930 (23); 1931 (34); 1935 (34); 1943 (41); 1961 (23); 2047 (1). 3635 (32); Lacerda,A.: 102 (31); 166 (3); 213 (11); 236 (23); 263 (23); 271 (4); 272 (6); Liebsch, D.: 390 (3); 
392 (34); 393 (3); 394 (41); 504 (33); 689 (23); MBM 299372 (34); MBM 299374 (41); Lindeman, J:: 257 (23); 2268 (34); 2511 (34); 2512 (34); 2537 (6); 2545 (34); 3045 (13); 3564 (34); 3842 (10); 4670 (41); 4909 (34); 5773 (2); 5775 (34); Mafra, M.: FUEL 2709 (3); Maieski, E.A.: 6 (2); Marquesini, N.: MBM 202562 (41); MBM 202566 (41); Maschio, W.: 163 (31); 1931 (2); Medri, C.: 524 (34); 882 (3); FUEL 26587 (3); RB 416292 (3); Meijer, A.: 58 (6); M.L.P.: 302 (13); Mocochinski,A.: 59 (32); 63 (35); 277 (5); 280 (32); 281 (32); 658 (32); Moreira, E.: 120 (11); Moro, R.: HUPG 9825 (26); HUPG 9939 (13); HUPG 10556(31); HUPG 10778 (3); HUPG 10964 (3); Mostasso, L.: FUEL 28906 (3); Motta, J.: 139 (41); 306 (10); 827 (23); 1029 (10); 1707 (34); 1718 (34); 1795 (41); 1989 (34); Nakano, E.M.: FUEL 28919 (2); Negrelle, R.: 120 (3); Nicolack, V.: 59 (30);Oliveira, H.: HUPG 6408 (2); Oliveira, P.I. : 544 (12); 608 (2); 685 (34); Paciornik.: 182 (6); 183 (34); 227 (41); 286 (31); Pasdiora,A.: 51 (34); 53 (34); 54 (36); 64 (35); 67 (35); 69 (29); 73(34); 74 (10); 75 (10); 76 (34); Paula, M.: de 36 (34);Pedersen.: 15955 (41); Pereira, E.: 6059 (34); 6096 (2); 8011 (13);Pliessnig,A.: HUPG 3790 (3); Poliquese, C.B.: 235 (6); 447 (13); 2111 (9); MBM 188550 (42); Possette, R.: 77 (41); MBM 298251 (31); UPCB 50470 (6); UPCB 50500 (34); Reginato, M.: 19 (4); 25 (34); 42 (1); 44 (6); 48 (23); 72 (23); 107 (23); 118 (23); 119 (25); 124 (34); 129 (32); 162 (24); 216 (23); 453 (35); 663 (11); Ribas, O.S.: 105 (34); 142 (34); 283 (41); 619 (34); 837 (2); 914 (34); 938 (6); 968 (35); 1066 (20); 1077 (11); 1099 (13); $2110(41) ; 2143$ (13); 2749 (37); 2762 (2); 2795 (34); $2814(41) ; 3043$ (10); 3139 (41); 3952 (13); 5798 (32); 6001 (34); Rizzini, R. B.: 80753 (6); Roderjan, C.V.: 224 (34); 1226 (2); 1359 (5); Ruas, P.: UPCB 39419 (13); Sá, K.L.V.: 177 (2); 261 (2);Saldanha, J.: 1791 (23); Santos, E.: 252 (23); 319 (34); 528 (35); 544, (32); 545 (32); 551 (32); 553 (32); 599 (32); 603 (32); 618 (23); 620 (24); 743 (35); 793 (32); 805 (32); 925 (23); 959 (1); Saueressig, D.: 334 (34); Scheer, M.: 228 (32); 239 (32); 246 (39); 267 (32); 268 (4); 277 (5); 283 (32); 385 (23); 386 (10); 388 (12); 429 (1); 430 (32); 657 (5); 660 (9); Schütz,A.: 51 (34); 66 (34); Schwartsburd, P.: UPCB 52512 (31); Silva, E.A.: UPCB 47354 (2);Silva, J.M.: 344 (34); 385 (41); 450 (12); 585 (35); 733 (23); 742 (16); 1181 (3); 1289 (20); 1308 (33); 1315 (1); 1392 (12); 1537 (2); $1588(6) ; 1598(41) ; 1614(34) ; 1617(23) ; 1718(4) ; 1791(23)$; 1792 (3); 2143 (34); 2304 (11); 3096 (23); 3177 (16); 3776 (34); 3970 (35); $4017(10) ; 4085$ (31); $4215(34) ; 4226(12)$; 4985 (31); MBM 245474 (42); Silva, S.M.: UPCB 34064 (31); Sobral, M.: 8523 (36); 8572 (10); 8582 (34); Souza, L.: 46 (41); Stange, E.: 65 (21); Stellfeld, C.: 12 (6); 609 (13); RB 49175 (15); Svolenski, A.C.: 309 (6); 361 (6); MBM 209357 (6); Tardin, J.: FUEL 23075 (3); Tessmann, G.: 2853 (13); 3078 (6); 3754 (6); 3756 (14); RB 69830 (6); Tiepolo, G.: 399 (41); 645 (41); 680 (34); 710 (31); Tomori, M.: 9 (3); Uhlman,A.: 44 (2); UPCB 25273 (6);Vieira,A.S.: 322 (3); 352 (34); 535 (2); FUEL 5889 (2); Vieira, F.: 793 (1); Vieira, M.: 65 (3); Von Lisingen, L.: 131 (31); 140 (2);Yasamoto, Y.: FUEL 28939 (2); Ziller, S.R.: 778 (6); 803 (10); 1948 (30). 